\title{
Exceeding Judicial Competence in the Name of Democracy: The German Federal Constitutional Court's OMT Reference
}

\author{
Mattias Wendel*
}

\begin{abstract}
First preliminary reference of the German Federal Constitutional Court - ECB Outright Monetary Transaction Programme (OMT) - Financial crisis - Ultra vires review - Principle of democracy - Judicial dialogue - Separation of powers National constitutional identity - Mandate of the ECB - Article 123 TFEU Article 18.1 ESCB-Statute - Economic and monetary policy - Honeywell test partially abandoned - Pringle judgment inverted - No margin of discretion for the ECB - Necessity, and prohibition of functional misuse, under Article 267 TFEU - Comparative reasoning
\end{abstract}

\section{INTRODUCTION}

'In an effort to secure the rule of law, a court may happen to exceed judicial competence. ${ }^{1}$ These introductory lines of a memorable dissenting opinion capture the internal tensions of a truly historic judgment. By order of 14 January 2014 the German Federal Constitutional Court (Bundesverfassungsgericht, FCC) took, for the very first time, the decision to refer a preliminary question to the European Court of Justice (ECJ). ${ }^{2}$

* Dr. iur. (Humboldt-University Berlin), Maîtr. en droit (Paris 1), senior fellow and lecturer at the Walter-Hallstein-Institute for European Constitutional Law, Humboldt-University Berlin. E-mail: mattias.wendel@hu-berlin.de. The author wishes to thank Paula Kift for exceptionally valuable support, Franz C. Mayer, Samo Bardutzky and Sebastian Leuschner for highly inspiring discussions and two anonymous reviewers for their rich and thoughtful comments. The usual disclaimer applies.

${ }^{1}$ Diss. opinion Lübbe-Wolff, FCC, Case 2 BvR 2728/13 et al. OMT, order of 14 Jan. 2014, para. 2.

${ }^{2}$ FCC, Case 2 BvR 2728/13 et al. OMT, order of 14 Jan. 2014. The decision was published on 7 Feb. 2014. EN translation available at: <www.bundesverfassungsgericht.de/en/decisions/ rs20140114_2bvr272813en.html. 
In essence, the Federal Constitutional Court's reference addresses the question of whether the so-called Outright Monetary Transactions (OMT) programme of the European Central Bank (ECB) is in conformity with EU law. The OMT programme goes back to an internal decision of the ECB's Governing Council that was communicated via press release on 6 September $2012 .{ }^{3}$ With this decision the bank established a framework for the purchase of a potentially unlimited amount of government bonds of select EU member states on the secondary market. According to the press release, a strict condition for any purchase is that the member states concerned implement a macroeconomic adjustment programme or a precautionary programme within the framework of the European Stability Mechanism (ESM) or its predecessor, the European Financial Stability Facility (EFSF). The announcement of the OMT programme was preceded by a statement by ECB President Draghi of 26 July 2012 that the Bank would do 'whatever it takes' within its mandate to save the euro. ${ }^{4}$ Until today, the OMT programme has not yet been put into effect and it probably never will be, given that its announcement alone had an immediate 'tranquilizing' effect on the financial markets.

The preliminary reference of the Federal Constitutional Court's Second Senate marks an important turning point in its case-law on European integration. While the Court had already evinced its general willingness to refer preliminary questions to the ECJ on several occasions in the past, ${ }^{5}$ it left a number of obvious opportunities to do so unexploited. ${ }^{6}$ The dialogue between the two courts is henceforth entering a new phase. Deeming the reference an act of submission or even a call for help for 'fear of its own courage , $^{77}$ would entirely miss the point. The preliminary ruling is not part of a hierarchically structured system of judicial review. It rather pays tribute to the idea of a functional allocation of judicial responsibilities in a multi-levelled setting, a setting within which the mandate for interpreting Union law is attributed to the ECJ - also and particularly vis-à-vis national constitutional courts.

While the very fact that Karlsruhe makes a preliminary reference to Luxembourg has thus to be strongly welcomed in general, the underlying legal premises of the

${ }^{3}$ Available at <www.ecb.europa.eu/press/pr/date/2012/html/pr120906_1.en.html>. According to the protocol of session 340 of the ECB's Governing Council of 5/6 Sept. 2012 the content of the decision was reproduced only in a press release. A formal record of the decision does not exist, cf. EGC, case T-492/12 von Storch u.a./EZB, order of 10 Dec. 2013, para. 2.

${ }^{4}$ Speech on the occasion of the 'Global Investment Conference in London' of 26 July 2012.

${ }^{5}$ Notably FCC, Case 1 BvR 256/08 et al. Data Retention, judgment of 2 March 2010, paras. 185-186.

${ }^{6}$ In particular FCC, Case 2 BvR 2236/04 European Arrest Warrant; FCC Data Retention, supran. 5 at paras. 185-186; FCC, Case 1 BvR 1215/07 Counter-terrorism Database, judgment of 24 April 2013, paras. 88-91.

${ }^{7}$ This is how the reference was perceived by some journalists, cf. Steltzner, Frankfurter Allgemeine Zeitung of 7 Feb. 2014. 
OMT reference remain highly questionable under the concrete circumstances. This is primarily due to the fact that the reference emanates from a so-called ultra vires review, i.e., the exercise of the FCC's self-proclaimed right to decide as a court of last instance whether an EU institution has transgressed its competences under the treaties. ${ }^{8}$ On the one hand, the Federal Constitutional Court brings the ECJ into the game, enabling the latter to give its interpretation of the Treaties with regard to OMT. On the other hand, the Bundesverfassungsgericht holds the view that it has to comply only 'in principle' with the ECJ's decisions as a binding interpretation of Union law. ' By claiming the right to carry out an ultra vires review, the FCC precisely undermines the ECJ's monopoly of interpretation under Article 19(1), second sentence, TEU and Article 344 TFEU which a preliminary reference is meant so secure. In this light, the OMT preliminary reference connects national constitutional law and EU law in an ominous way. The two dissenting opinions of senior Judges Lübbe-Wolff and Gerhardt bear witness to just how controversial the decision was even within the Second Senate.

The German Federal Constitutional Court's OMT reference (next para.) al ready raises serious concerns from the perspective of national constitutional law (para. 'Constitutional law perspective'). The reference, which resembles a call for allegiance rather than a question, is also highly questionable on account of its discussion of EU law - particularly in consideration of the reactions it may elicit in Luxembourg (para. 'EU law perspective and Luxembourg's range of options'). Insofar as Karlsruhe relies on comparative law, however, the Court's argument reveals an interesting transnational dimension which goes beyond the framework of national constitutional and EU law in a narrower sense (para. 'Transnational dimension: Comparative legal reasoning). It is the sad irony of the OMT reference that, in a doubtlessly well-intentioned effort to protect the principle of democracy against an alleged excess of competences at the EU level, the FCC itself exceeds the limits of its judicial mandate under German constitutional and EU law. Against this backdrop, one might finally ask which particular role constitutional courts could constructively play within the framework of a preliminary reference procedure (para. 'Outlook: What role for constitutional courts in preliminary ruling proceedings').

\section{The OMT Reference: Context AND MAIn ARgument}

The preliminary reference is embedded in the context of EU-wide efforts to overcome the financial crisis. Contrary to all promises of efficient crisis management

\footnotetext{
${ }^{8}$ For an in-depth analysis of the concept, see F.C. Mayer, Kompetenzüberschreitung und Letztentscheidung (Beck 2000), p. 11 et seq.

${ }^{9}$ FCC OMT, supra n. 2 at para. 24 with reference to FCC, Case 2 BvR 2661/06 Honeywell, order of 6 July 2010.
} 
by the executive, the increasing shift towards inter-governmental decision-making has not only demonstrated a distressing degree of inefficiency, but first and foremost has posed a fundamental threat to the democratic decision-making processes at national and EU level. ${ }^{10}$

\section{Precedential context}

Against this backdrop, it is not surprising that the principle of democracy lies at the heart of the Federal Constitutional Court's crisis-related jurisprudence. The OMT reference is just one of several decisions that assess the 'rescue measures' from this particular angle of the German Basic Law (Grundgesetz-GG). First decisions of the Court tackled the constitutionality of the domestic approval to bilateral financial aids for Greece and the EFSF, ${ }^{11}$ but also the particular modes of parliamentary involvement ${ }^{12}$ and parliamentary rights to information. ${ }^{13}$ Other national constitutional or supreme courts that reviewed the constitutionality of rescue measures or their domestic implications $s^{14}$ include the Supreme Court of Estonia, ${ }^{15}$ the French Constitutional Council, ${ }^{16}$ the Irish Supreme Court, ${ }^{17}$ the Portuguese Constitutional Tribunal, ${ }^{18}$ the Polish Constitutional Tribuna ${ }^{19}$ and the Austrian Constitutional Court. ${ }^{20}$

\footnotetext{
${ }^{10}$ For reform proposals aiming at strengthening the democratic decision-making processes see I. Pernice et al. (eds.), A Democratic Solution to the Crisis (Nomos 2012) p. 104 et seq.; Group 'Glienicke', 'Towards a Euro Union' (available at <www.glienickergruppe.eu/english.html>); M. Poiares Maduro et al. (eds.), 'The Democratic Governance of the Euro', 8 RSCAS Policy Paper (2012).

${ }^{11}$ FCC, Case 2 BvR 987/10 et al. Greece \& EFSF, judgment of 7 Sept. 2011, para. 101. For a critical and in-depth analysis of several reform proposals see P. Leino and J. Salm, 'Should the Economic and Monetary Union Be Democratic after All?', 14 GLJ (2013) p. 844, 863 et seq.

${ }^{12}$ FCC, Case 2 BvE 8/11 Special Parliamentary Committee, judgment of 28 Jan. 2012, paras. 113 et seq.

${ }^{13}$ FCC, Case 2 BvE 4/11 Right to information (ESM \& Euro Plus Pact), judgment of 19 June 2012, paras. 94 et seq., 107.

${ }^{14}$ For a comparative overview see E. Fahey and S. Bardutzky, 'Judicial Review of Eurozone Law', MJIL (2013) p. 101, 105 et seq.; Fabbrini, 'The Euro-Crisis and the Courts', Berkeley Journal of International Law (2014 forthcoming).

${ }^{15}$ Estonian Supreme Court, Case 3-4-1-6-12 ESM, judgment of 12 July 2012.

${ }^{16}$ French Conseil constitutionnel, Case 2012-653 DC TSCG, decision of 9 Aug. 2012.

${ }^{17}$ Irish Supreme Court, Case 2012 OJ (C 303) 18 Pringle, decision of 31 July 2012.

${ }^{18}$ Portuguese Constitutional Court, Case 353/2012 State Budget Law 2012 and Case 187/2013 State Budget Law 2013, judgment of 5 April 2013.

${ }^{19}$ Polish Constitutional Tribunal, Case K 33/12 Amendment of Article 136 TFEU, judgment of 26 June 2013.

${ }^{20}$ Austrian Constitutional Court, Case SV 1/2013-15 TSCG, judgment of 3 Oct. 2013.
} 


\section{ESM \& TSCG Decision of 12 September 2012 (summary review)}

The proceeding, in the course of which the Bundesverfassungsgericht finally decided to take the road to Luxembourg, is one of the largest in the entire history of the Court. The number of individual complainants alone amounted to more than 37,000, an unparalleled number. Moreover, the proceeding was accompanied by an unprecedented media hype that reached its climax just before the decision of 12 September 2012 when the whole world seemed to look at the relatively small city of Karlsruhe. In its much-noted decision ${ }^{21}$ - the paragraphs of which have recently been renumbered ${ }^{22}$ - the FCC allowed Germany, on the basis of a summary review, to ratify the three challenged reform instruments, i.e., the amendment of Article 136 TFEU, ${ }^{23}$ the ESM Treaty ${ }^{24}$ and the Treaty on Stability, Coordination and Governance (TSCG) ${ }^{25}$ at a relatively early stage and far ahead of the decision on the principal proceedings. While the Court did not identify constitutional obstacles to the ratification of the amendment of Article 136 TFEU and the TSCG, it permitted the ratification of the ESM Treaty only on two conditions. Both requirements were addressed immediately in the aftermath of the decision by an interpretative declaration of the contracting parties. ${ }^{26}$ In substantive terms, the decision of 12 September 2012 was characterized particularly by a remarkably strong manifestation of judicial restraint. ${ }^{27}$

${ }^{21}$ FCC, Case 2 BvR 1390/12 et al., ESM \& TSCG (summary review), judgment of 12 Sept. 2012. The accompanying legislation, particularly the ESM financing law, was also subject to review. For case notes in English see particularly the contributions in 14 GLJ (2013) p. 1 et seq.

${ }^{22}$ The decision was originally divided into 319 paragraphs, see still NJW (2012) p. 3145; EuR (2013) p. 75; DVBl (2012) p. 1370. The renumbered DE version now (2014) comprises only 215 paragraphs. However, the EN translation (available at <www.bundesverfassungsgericht.de/ entscheidungen/rs20120912_2bvr139012en.html $>$ ) is still based on the original numbering with a total of 319 paragraphs. To make it even more complicated, the preliminary EN version published on 12 Sept. 2012 was incomplete at the time and consisted only of 240 paragraphs (the numbering of which did not correspond to the DE version at the time). This article refers to the EN version of 2014 with 319 paragraphs [EN 2014].

${ }^{23}$ European Council Decision, 25 March 2011, EUCO 10/11, ANNEX II, p. 21, in force since 1 May 2013.

${ }^{24}$ Treaty establishing the European Stability Mechanism, signed on 2 Feb. 2012, in force since 27 Sept. 2012.

${ }^{25}$ Treaty on Stability, Coordination and Governance in the Economic and Monetary Union (TSCG), also known as the 'Fiscal Treaty' or 'Fiscal Compact', signed on 2 March 2012 by all EU member states except the Czech Republic and the UK, in force since 1 Jan. 2013.

${ }^{26}$ Declaration on the ESM of 27 Sept. 2012, available at: <www.consilium.europa.eu/uedocs/ cms_data/docs/pressdata/en/ecofin/132615.pdf>.

${ }^{27}$ In detail M. Wendel, 'Judicial Restraint and a Return to Openness', 14 GLJ (2013), p. 22, 41 et seq. 


\section{ESM \& TSCG decision of 18 March 2014 (principal proceedings)}

Even though the Federal Constitutional Court had already clarified the most fundamental legal questions in its decision of 12 September 2012, it deliberately left open several aspects for a more in-depth examination. These leftovers include the legal assessment of the European Central Bank's crisis management on the one hand and several constitutional questions related to admissibility and parliamentary participation on the other hand. Whereas the former leftovers led to the OMT preliminary reference, the latter were addressed in the judgment on the principal proceedings of 18 March $2014 .^{28}$ This judgment largely meets previous expectations as it essentially amounts to a repetition of the earlier summary review and specifies several questions related to admissibility and parliamentary participation. For instance, the Court declares the applications in the inter-institutional proceeding (Organstreit) inadmissible insofar as they aim at a two-thirds majority requirement for parliamentary approval for certain decisions under the ESM. ${ }^{29}$

\section{Decisions at EU level}

At EU level, both the Court of Justice and the General Court have dealt with questions related to the financial crisis. In its landmark decision on Pringle the ECJ declared that the introduction of Article 136(3) TFEU on the basis of the simplified amendment procedure as well as the conclusion and ratification of the ESM Treaty by the member states of the Eurozone, were in conformity with EU law. ${ }^{30}$ The thesis according to which normativity was replaced by mere necessity during the crisis ${ }^{31}$ was countered by the Grand Chamber with a methodologically sound reasoning. ${ }^{32}$ In particular the ECJ demonstrated why the so-called 'no-bailout clause' (the somewhat misleading popular denomination of Article 125 TFEU) had not been infringed. ${ }^{33}$ This question had been vigorously debated in the literature before. ${ }^{34}$

${ }^{28}$ FCC, Case 2 BvR 1390/12 et al., ESM \& TSCG (principal proceedings), judgment of 18 March 2014.

${ }^{29}$ Ibid., para. 157.

${ }^{30}$ ECJ, Case Rs. C-370/12 Pringle, judgment of 27 Nov. 2012.

${ }^{31}$ See Ch. Joerges, 'Europas Wirtschaftsverfassung in der Krise', 51 Der Staat (2012) p. 357, 378-381 with further references. Critically (and justifiably so) D. Thym, $J Z$ (2013) p. 259 et seq.

${ }^{32}$ Which - with a view to the judgment's audience - is certainly not only coincidentally based on a Savigny approach, see D. Thym and M. Wendel, 'Préserver le respect du droit dans la crise', Cahiers de droit européen (2012) p. 733, 744-745, 753-754.

${ }^{33}$ ECJ Pringle supra n. 30 at paras. 129-147.

${ }^{34}$ The discussion already started with bilateral financial aids and the EFSF, see exemplarily on the one hand Ruffert, 'The European Debt Crisis and European Law', 48 CMLRev. (2011) p. 1777, 1785-1787 (violation of Art. 125 TFEU) and on the other hand de G. Merino, 'Legal 
It is a fruitful exercise to compare Pringle with the Bundesverfassungsgericht's ESM decisions, most notably in terms of legal standards and methodological approaches, but also as regards the decisions' results, which can be considered functionally equivalent. ${ }^{35}$ Above all, Pringle constitutes an eminent point of reference for Karlsruhe in its OMT reference. However, as we will see, the Federal Constitutional Court essentially inverts the ECJ's key argument in a way that is highly questionable under EU law.

The only institution at EU level that has been directly confronted with the validity of actions taken by the European Central Bank during the crisis so far is the General Court. By order of 16 December 2011 it rejected the individual action for annulment directed against the ECB's Securities Markets Programme (SMP) as inadmissible. ${ }^{36}$ By order of 10 December 2013 the General Court also rejected the individual action for annulment directed against OMT as inadmissible. ${ }^{37}$ The General Court rightly pointed out that the claimants - more than 5,000 and almost all of them also engaged before the German Federal Constitutional Court - failed to demonstrate that they were directly concerned by the OMT programme, given that its implementation depended on further acts within the discretionary power of the European Central Bank. However, the General Court explicitly highlighted the possibility that the applicants could challenge future implementing acts before national courts and, within this framework, could try to initiate a preliminary reference to the Court of Justice. ${ }^{38}$

\section{The OMT reference in a nutshell}

Exactly one week after the General Court had rejected the action against OMT as inadmissible, the German Federal Constitutional Court separated the applications relating to the European Central Bank's activities from the main proceedings in the ESM case. ${ }^{39}$

developments in the Economic and Monetary Union During the Debt Crisis', 49 CMLRev. (2012) p. 1613, 1626-1630 (compatibility with Art. 125 TFEU under certain conditions).

${ }^{35}$ For a closer examination see Thym and Wendel, supra n. 32 at p. 749 et seq. and Ch. Calliess, 'Der ESM zwischen Luxemburg und Karlsruhe', $N V w Z$ (2013) p. 97, 99 et seq.

${ }^{36}$ The time limit under Art. 263(6) TFEU had expired, EGC, Case T-532/11 Städter/EZB, order of 16 Dec. 2011, paras. 7 et seq.; affirmed by ECJ, Case C-102/12 P Städter/EZB, order of 15 Nov. 2012.

${ }^{37}$ EGC, Case T-492/12 von Storch u.a./EZB, judgment of 10 Dec. 2013, paras. 35, 38 et seq.

${ }^{38}$ Ibid., para. 47.

${ }^{39}$ FCC, Case 2 BvR 1390/12 et al., OMT-separation, order of 17 Dec. 2013. As a matter of fact, the applications that explicitly addressed the OMT programme had been submitted not until the aftermath of the FCC's interlocutory decision of 12 Sept. 2012. Prior to this date, only one group of claimants had raised an ultra vires claim in relation to bond purchases by the ECB on the secondary market. 
By referring preliminary questions the Bundesverfassungsgericht essentially wants to see its own legal interpretation confirmed, according to which the OMT programme, firstly, is not covered by the mandate of the ECB and second, violates Article 123 TFEU. According to the Federal Constitutional Court, the OMT is to be seen predominantly as a measure of economic policy which exceeds the competences attributed to the European Central Bank under EU primary law and encroaches upon the competences of EU member states in the field of economic policy. This assessment is based on a variety of observations, namely the programme's objectives, the fact that it envisages the purchase of government bonds only of select member states (selectivity), the circumstance that it is linked to economic reform programmes under the EFSF or ESM (conditionality), or rather that it envisages the purchase of bonds in addition to these assistance programmes (parallelism), the terms and conditions of which might thus be undermined (bypassing) ${ }^{40}$ In short, in the eyes of the Court the OMT programme resembles a functional equivalent to the reform programmes - an equivalent, however, which lacks the necessary degree of parliamentary legitimation and control.

The second violation of EU primary law identified by the Federal Constitutional Court consists in a forbidden circumvention of Article 123 TFEU (prohibition of monetary financing). Beyond the arguments already mentioned, the Court particularly refers to the following aspects in order to support its claim: the lack of a quantitative limitation of the envisaged purchase of government bonds ( volume); an alleged absence of a time lag between possible purchases by the ECB on the secondary market and their prior emission on the primary market (market pricing); the possibility of holding purchased government bonds to maturity (interference with market logic); the lack of any specific requirements on credit ratings of the government bonds to be purchased (default risk); the equal treatment of the European System of Central Banks and private as well as other government bondholders (debt cut $)^{41}$; and last but not least the ECB's (indirect) encouragement of market participants to purchase said bonds on the primary market (encouragement to purchase newly issued securities). ${ }^{42}$

Although the Federal Constitutional Court considers the alleged violations to be manifest, it holds the view that the OMT programme could still be interpreted in accordance with EU law, most notably if its implementation was limited in such a way that it would not undermine the conditionality of the reform programmes and would only be of a supportive nature with regard to the economic policies in the Union. With regard to Article 123(1) TFEU, this would, according to the Court, require particularly the exclusion of a debt cut, a quanti-

\footnotetext{
${ }^{40}$ FCC OMT, supra n. 2, question no. 1 lit. a.

${ }^{41}$ Ibid., question no. 1 lit. b.

${ }^{42}$ This aspect is only raised within the context of auxiliary question no. 2 lit. b ff.
} 
tative limitation of bond purchases ex ante and last but not least the prevention of interferences with market price formation 'where possible'. ${ }^{43}$ In other words, the Bundesverfassungsgericht aims at establishing red lines for a programme whose implementation is likely rendered unnecessary by virtue of the effectiveness of its mere announcement.

When comparing the OMT case with earlier proceedings before the German Federal Constitutional Court, one should note a fundamental difference: unlike its predecessors the OMT case does not address the constitutional review of intergovernmental crisis management, a policy for which the federal government is accountable to the federal parliament (Bundestag) and on which the Bundestag must have a continuous and decisive say. Instead, in OMT the Court (indirectly) reviews actions of the European Central Bank, an institution designed and expected to be independent according to both EU law (Article 130 TFEU) and constitutional law (Article 88(2) GG) - independent also, if not particularly, from the parliament. ${ }^{44}$

\section{Constitutional LaW Perspective}

The OMT reference already raises several serious concerns from the perspective of national constitutional law.

Plus ultra: the expansion of ultra vires review

Regarding the conditions of ultra vires review, the decision departs from previous case law in several ways.

Ultra vires review: conceptual foundations and precedents

The concept of ultra vires review is a product of judicial lawmaking. Against the explicit suggestion of the Bundesverfassungsgericht ${ }^{45}$ the German (constitutional) legislature has until today refrained from enacting specific procedural provisions for the exercise of ultra vires or identity review. ${ }^{46}$

As is well known, the German Federal Constitutional Court's claim to decide whether EU institutions have exceeded their competences is not a new phenom-

${ }^{43}$ FCC OMT, supra n. 2 at para. 100.

${ }^{44}$ Cf. already FCC, Case 2 BvR 2134, 2159/92 Treaty of Maastricht, judgment of 12 Oct. 1993, para. 154. The FCC also refers to this precedent, see FCC OMT, supra n. 2 at para. 32.

${ }^{45}$ FCC, Case 2 BvE 2/08 et al. Treaty of Lisbon, judgment of 30 June 2009, para. 241.

${ }^{46}$ Discussion of relevant suggestions in M. Wendel, Permeabilität im europäischen Verfassungsrecht (Mohr Siebeck 2011) p. 479 et seq. 
enon. ${ }^{47}$ In the Court's case-law this approach was foreshadowed as early as $1971,{ }^{48}$ followed by increasingly articulate indications in $1981^{49}$ and $1987 . .^{50}$ The first open claim to review whether acts of EU law exceed the competencies attributed to the EU was made in the Maastricht judgment of $1993,{ }^{51}$ the essence of which had already been anticipated by the academic writings of judge rapporteur Paul Kirchhof. ${ }^{52}$ The practical modalities as well as the conceptual foundation of this judicial reservation were further substantiated in the Lisbon judgment of 2009, henceforth under the topos of 'ultra vires review. ${ }^{53}$ As a consequence of the constitutional principle of 'openness towards European law' (Europarechtsfreundlichkeit), the Court restricted ultra vires review to 'obvious transgressions' and to situations in which legal protection could not be obtained at EU level. ${ }^{54}$ In Lisbon, the Second Senate also clarified that within the domestic judicial system only the Federal Constitutional Court itself shall be entitled to carry out an ultra vires review. ${ }^{55}$ In substance, the Court also included adherence to the principle of subsidiarity within its ultra vires review. ${ }^{56}$

The Lisbon judgment also refined the idea of conceptualising the principle of conferral through the lens of national constitutional law. According to the Court, the principle of conferred powers is not only a principle of EU law, but the 'expression of the foundation of Union authority in the constitutional law of the Member States'. ${ }^{57}$ Despite of its own claim of autonomy, ${ }^{58} \mathrm{EU}$ law is thus reduced to a mere derivative of national sovereign powers, ${ }^{59}$ an interpretation which conceptually misses the fact that the 'transfer of powers' as addressed by several national

\footnotetext{
${ }^{47}$ For an in-depth analysis see Mayer supra n. 8 at p. 87 et seq.; Wendel, supra n. 46 at p. 462 et seq.; M. Claes, The National Courts' Mandate in the European Constitution (Hart 2006) p. 709 et seq.; H. Sauer, Jurisdiktionskonflikte in Mehrebenensystemen (Springer 2008) p. 179 et seq.; M. Kumm, 'The Jurisprudence of Constitutional Conflict', ELJ 11 (2005) p. 262, 264, 295 ff.

${ }^{48}$ FCC, Case 2 BvR 255/69 Lütticke, order of 9 June 1971, BVerfGE 31, p. 145, 174.

${ }^{49}$ FCC, Case 2 BvR $1107 / 77$ et al., Eurocontrol I, order of 23 June 1981, BVerfGE 58, p. 1, 30 et seq.

${ }^{50}$ FCC, Case 2 BvR 687/85 Kloppenburg, order of 8 April 1987, BVerfGE 75, p. 223, 235.

${ }^{51}$ FCC Maastricht supra n. 44 at para. 106.

${ }^{52}$ P. Kirchhof, 'Deutsches Verfassungsrecht und Europäisches Gemeinschaftsrecht', in P. Kirchhof and C.D. Ehlermann (eds.), Europarecht Beiheft 1/1991, p. 11, 18.

${ }^{53}$ FCC Lisbon supra n. 45 at paras. 240 and 340.

${ }^{54}$ Ibid., para. 240.

${ }^{55}$ Ibid., para. 241.

${ }^{56}$ Ibid., para. 240.

${ }^{57}$ Ibid., para. 234.

${ }^{58}$ ECJ, Case Rs. 26/62 Van Gend \& Loos, judgment of 5 Feb. 1963, paras. 9-10; ECJ, Case 6/64 Costa/ENEL, judgment of 15 July 1964, paras. 8 et seq. As a classic cf. J.H.H. Weiler and U.R. Haltern, 'The Autonomy of the Community Legal Order through the Looking Glass', 37 HILJ (1996), p. 411 et seq.

${ }^{59}$ Ibid., para. 231 and further also para. 301. Different approach still in FCC, Case BVerfGE 22, 293, 296 EEC regulations and Case BVerfGE 31, 145, 173-174, Milk Powder.
} 
integration clauses is not a transferre, but instead a conferre. ${ }^{60}$ The German Federal Constitutional Court's ultra vires review essentially aims to ensure that the exercise of public authority at EU level does not exceed the so-called 'integration programme' which has been consented to, in Germany, by an act of parliament. In Karlsruhe's conception, the parliamentary statutes of approval to the Treaties are a bridge connecting national law with EU law - a bridge at the end of which stands a guardian: the Bundesverfassungsgericht. ${ }^{61}$ However, the substantial scope of a statute of approval can only be determined in relation to its point of reference: EU primary law. That is the reason why the ultra vires review cannot be conceptually limited to (directly or indirectly) scrutinizing the compatibility of EU law with national constitutional law, but necessarily extends to examining whether EU secondary law is in conformity with EU primary law.

This twofold review standard, with its roots deep in national constitutional law but with its branches stretching out into EU law, presents a fundamental conceptual problem, ${ }^{62}$ given that the Federal Constitutional Court is adjudicating in an area for which it is not competent, neither in a legal nor in a technical sense. Or to use another metaphor: the FCC looks at the European order of competences through the lens of national constitutional law, thus producing an image that is not necessarily congruent with the self-portrait of EU law. The more the Court extends its review competence on detailed questions of EU law, the higher the degree of distortion. Furthermore there is always the danger of methodological incoherence, particularly when a national constitutional court like the FCC critiques the Court of Justice for a certain way of interpretation (dynamic, teleological, broad etc.) which resembles the methods used by the national court itself when interpreting national constitutional law. ${ }^{63}$

How can the functionality of EU law be maintained within the framework of an ultra vires review on the basis of these premises? The FCC elaborated on this question in its Honeywell ruling. ${ }^{64}$ The Court emphasized the necessity to coordinate the ultra vires review 'with the task which the Treaties confer on the Court of Justice, namely to interpret and apply the Treaties, and in doing so to safeguard the unity and coherence of Union law' ${ }^{65}$ In light of the principle of openness towards European law, the FCC specified the procedural and substantial conditions

\footnotetext{
${ }^{60}$ See already E. Kaufmann, in Institut für Staatslehre und Politik Mainz (Ed.), Der Kampf um den Wehrbeitrag (vol. II, 1953) p. 42, 55.

${ }^{61}$ For this metaphor see Kirchhof, supra n. 52 at p. 15.

${ }^{62}$ Compare F.C. Mayer, 'Rebels without a Cause?', GLJ (2014) p. 111, 117.

${ }^{63}$ P. Craig, 'The ECJ and Ultra Vires Action', 48 CMLRev. (2011) p. 395, 405.

${ }^{64}$ FCC, Case 2 BvR 2661/06 Honeywell, order of 6 July 2010.

${ }^{65}$ FCC Honeywell, supra n. 64 at para. 56.
} 
for ultra vires review in several ways, ${ }^{66}$ thereby omitting any reference to the concept of 'sovereign statehood' that had played a key role in the Lisbon judgment.

In terms of procedure the FCC made it unambiguously clear that the Court of Justice must be given an 'opportunity to interpret the Treaties, as well as to rule on the validity and interpretation of the legal acts in question' before the FCC decides on the inapplicability of an act of EU law in Germany. ${ }^{67}$ Meeting this requirement is in and of itself doubtlessly a great achievement of the OMT reference.

In terms of substance, according to Honeywell a double test applies: ultra vires review can only 'be considered' by the FCC if the act of EU law in question is firstly 'manifestly in violation of competences' and secondly structurally significant, i.e., 'highly significant in the structure of competences between the Member States and the Union with regard to the principle of conferral and to the binding nature of the statute under the rule of law. ${ }^{68}$ In this context the Federal Constitutional Court did not only express respect for the Union's own, idiosyncratic legal methodology, but also granted the ECJ a 'right to tolerance of error' ${ }^{69}$ Judge Landau criticized in his dissenting opinion that this restrictive concretization of ultra vires review fell short of the judicial consent reached by the Second Senate in its Lisbon judgment ${ }^{70}$; yet another example for the Lisbon judgment's diversity of (and openness to) interpretations. ${ }^{71}$

Even though the Federal Constitutional Court suggests that the OMT decision is in line with its Honeywell judgment, ${ }^{72}$ a closer look reveals several important deviations.

\section{Extending ultra vires review to legal prohibitions}

The first consists in the explicit extension of ultra vires review to compliance with legal prohibitions under EU primary law. By including an alleged violation of Article 123 TFEU in its OMT reference, the Second Senate extends ultra vires review to the question whether an act of an EU institution is in conformity with provisions of EU primary law - provisions which are categorically no legal bases in the strict sense of the word. This move is certainly not spectacular, given that a legal prohibition can always be reconstructed as a negative competence norm. The

${ }^{66}$ Cf. M. Payandeh, 'Constitutional Review of EU Law after Honeywell', 48 CMLRev. (2011) p. 9, 23 et seq.; H. Sauer, 'Europas Richter Hand in Hand?', EuZW (2011) p. 94, 95, 97; Classen, JZ (2010), p. 1186.

${ }^{67}$ FCC Honeywell supra n. 64 at para. 60.

${ }^{68}$ Ibid., at para. 61.

${ }^{69}$ Ibid., at para. 66.

${ }^{70}$ Diss. opinion Landau zu BVerfGE 126, 286 (322) Rn. 102 - Honeywell.

${ }^{71}$ F.C. Mayer, 'Rashomon in Karlsruhe', NJW (2010) p. $714 \mathrm{ff}$.

${ }^{72}$ FCC OMT, supra n. 2 at paras. 24-26. 
danger that this leads to a path at the end of which stands a general EU legality review by the FCC could certainly be averted if the Honeywell double test was strictly applied.

\section{Manifest violation of competences?}

In the aftermath of the OMT reference it is questionable, however, if the Honeywell test still applies in sensu stricto. With a view to potential redistributive effects on the one hand ${ }^{73}$ and the overall fiscal responsibility of the parliament on the other hand ${ }^{74}$ one could still agree with the FCC where it classifies the alleged violations as being of structural importance. ${ }^{75}$

However, this is not true for the second criterion of the Honeywell test, i.e., the condition that the EU act in question must be in manifest violation of competences. Although the Second Senate formally holds on to this condition, its concrete application illustrates that substantially there is not much left of it. ${ }^{76}$ As indicated above, the restriction of ultra vires review to manifest violations of competences is meant to guarantee the functionality and unity of EU law. This requirement would be met if one conceived of manifest violations as merely those which are 'obvious from the outset and which suggest themselves without further legal analysis', as Judge Gerhardt submits in his dissenting opinion. ${ }^{77}$ Certainly, the claim that a violation is manifest cannot be disproved by the mere fact that a counterargument can theoretically be formulated. Legal questions are always debatable, also (and not rarely so) on the basis of odd legal positions. Meanwhile, a qualification like 'evident' or 'manifest' demands an increased degree of persuasiveness. Hence, in order to establish a manifest violation of competences, adequate reasons would have to be provided why the assumption of a breach of competences is clearly preferable to any other legal position defended. This standard is - inversely-used by the FCC in order to establish whether ordinary or specialized courts have arbitrarily violated German constitutional law by not referring a preliminary question to the Court of Justice in Luxembourg. ${ }^{78}$

${ }^{73}$ Ibid., paras. 40-41.

${ }^{74}$ Ibid., paras. 43-44.

${ }^{75}$ Critical, however, J. Bast, 'Don't Act beyond Your Powers', 15 GJL (2014) p. 167, 179-180.

${ }^{76}$ For similar conclusions, see W. Heun, 'Eine verfassungswidrige Verfassungsgerichtsentscheidung', JZ (2014) p. 331, 332 and A. Thiele, 'Friendly or Unfriendly Act?', 15 GJL (2014) p. 242, 254 et seq.

${ }^{77}$ Diss. opinion Gerhardt, FCC, Case 2 BvR 2728/13 et al., OMT, order of 14 Jan. 2014, para. 16.

${ }^{78}$ FCC, Case 2 BvL 12, 13/88 Absatzfonds, 31 May 1990, para. 137. Accordingly, an ordinary or specialized court of last instance violates the right to a lawful judge arbitrarily (Art. 101(1), second sentence, GG) 'when possible counterarguments are clearly preferable to the opinion held by the court on the relevant question' of EU law. Note: the jurisprudence of both senates of the 
The Federal Constitutional Court's line of argument in its OMT reference, however, does not and could not possibly generate such an elevated degree of persuasiveness. After all, the FCC's legal assessment is based on premises of EU law that are, as we will see, highly questionable, and in any case not obviously preferable to other legal positions.

While leaving little doubt that it considers the OMT programme both a breach of the mandate of the ECB as well as a forbidden circumvention of Article 123 TFEU, the majority of the Second Senate explicitly states that this assessment is 'subject to the interpretation by the Court of Justice'. ${ }^{79}$ This makes it all the more astounding that the FCC establishes the manifest character of a - so far only hypothetical - violation of Article 123 TFEU in a single sentence:

The violation would be manifest because the Treaty on the Functioning of the European Union stipulates an explicit prohibition of monetary financing of the budget and the Treaty thus unequivocally excludes such powers of the European Central Bank (cf. Article 123(1) TFEU). ${ }^{80}$

From the apodictic assumption that Article 123 TFEU 'unequivocally excludes such powers', the Second Senate's majority concludes that a violation - in case there was one - would also be manifest. First of all, Article 123 TFEU is not, as we will see, as unequivocal as the Court suggests. Second, if the truth of the implication's antecedent ('OMT is monetary financing') is only established after a process of investigation that might have produced a different result, then to conclude, nonetheless, that the consequence ('OMT is ultra vires') is manifestly true is very strained logic.

Furthermore, the majority of the Second Senate insists on there having been a manifest violation, it at the same time suggests that 'concerns regarding the validity of the OMT Decision (...) could be met by an interpretation in conformity with Union law' ${ }^{81}$ But if we assume that an act could be regarded as being in conformity with EU law by means of interpretation, how could this very act simultaneously be regarded as manifestly violating EU competences? ${ }^{82}$ The two dissenting opinions are more convincing in this respect. In the view of Judges Lübbe-Wolff and Gerhardt, the constitutional complaints as well as the applications in the inter-institutional proceeding should have been rejected as inadmis-

FCC is not coherent in this respect, see FCC Honeywell, supra n. 64 at para. 89. For more details cf. the controversy between Fastenrath and Michael in $J Z$ (2012) p. 870 et seq. and $J Z$ (2013) p. 299 et seq. and 203 et seq.

${ }^{79}$ FCC OMT, supra n. 2 at para. 55.

${ }^{80}$ Ibid., para. 43.

${ }^{81}$ Ibid., para. 99.

${ }^{82}$ See I. Pernice, Verfassungsblog of 10 Feb. 2014. 
sible. If the Court had so decided, however, the preliminary questions would have definitely been irrelevant under Article 267 TFEU. The majority of the Second Senate obviously wanted to prevent such a result.

The Federal Constitutional Court thus comes to the paradoxical result of asking the Court of Justice whether or not the OMT programme violates EU law, while claiming at the same time that the violation, if established, would necessarily have to be considered manifest. ${ }^{83}$ In other words, in order to even be entitled to ask whether there is a violation, the FCC already has to qualify it as such. ${ }^{84}$

The fact that the Federal Constitutional Court considers OMT to be in violation of the Treaties 'subject to the interpretation of the Court of Justice ${ }^{85}$ can, on the other hand, not only be understood as an (offensive) invitation to the ECJ to restrict the implications of the OMT programme by means of interpretation. On the basis of this section the FCC could, in its final judgment, also accept the ECJ's finding in a spirit of cooperation even in case that Luxembourg does not follow the interpretation of Karlsruhe - at least as far as the latter does not carry out an identity review.

\section{Extraordinary legal protection under extraordinary circumstances?}

With its OMT reference, the Second Senate acknowledges for the first time a 'principal ultra vires objection', ${ }^{86}$ be it within the procedural framework of an inter-institutional proceeding ${ }^{87}$ or a constitutional complaint. ${ }^{88}$ The admissibility of a constitutional complaint thus neither depends on a link between the ultra vires objection and the claimant's principal claim that a substantial fundamental right has been violated (as was the case in Honeywell), ${ }^{89}$ nor on the claim that the essence of the right to vote - protected by the eternity clause in Article 79(3) GG - has been violated by an ultra vires act. According to the Second Senate,

citizens who are entitled to vote generally have a right, deriving from [the right to vote], to have a transfer of sovereign powers only take place in the ways envisaged in [the German integration clause in combination with the stipulation demanding

${ }^{83}$ Ibid.

${ }^{84}$ This is particularly due to the fact that the Federal Constitutional Court acknowledges, for the first time, a principal ultra vires objection, see infra.

${ }^{85}$ Supra n. 79.

${ }^{86}$ Aptly K. Schneider, 'Yes, But...One More Thing: Karlsruhe's Ruling on the European Stability Mechanism', 13 GLJ (2012) p. 53, 57 and id., 'Questions and Answers', 15 GLJ (2014) p. 218, 222.

${ }^{87}$ FCC OMT, supra n. 2 at para. 54.

${ }^{88}$ Ibid., at paras. 51-53.

${ }^{89}$ The question was if a specialized court violated the fundamental rights of an individual because it had aligned its jurisprudence to the ECJ's Mangold judgment which was considered by some observers to be ultra vires. 
a two thirds majority for constitutional amendments]. The democratic decisionmaking process, which these regulations guarantee in addition to the necessary specificity of the transfer of sovereign powers (...), is undermined when there is a unilateral usurpation of powers by institutions and other agencies of the European Union. ${ }^{90}$

This is a paradigm shift. The right to vote henceforth entitles the voter to demand compliance with the procedural conditions of the EU-specific provisions of the German Basic Law as far as he or she claims the existence of an ultra vires act. In the numerous precedents relating to European integration, the right to vote could, however, only be invoked in case that the complainants plausibly demonstrated that by transferring competences or authorizing financial commitments, the Bundestag would lose its continuous and decisive say in fields which the Bundesverfassungsgericht considers to be essential for shaping the political development in Germany. This standard of review was intrinsically linked with the very essence of the principle of democracy as protected by the so-called 'eternity clause' even against constitutional revision (Article 79(3) GG). ${ }^{91}$ This link has now been dissolved. ${ }^{92}$

The new expansion of the review competences of the Federal Constitutional Court proves early critics right. ${ }^{93}$ When the Court explicitly confirmed ${ }^{94}$ its jurisprudence on the right to vote in 2011 with reference to the ample and substantive criticism in the literature, it did so precisely by referring to this unchangeable essence of the principle of democracy. If the parliament gave up key elements of political self-determination and thus permanently deprived citizens of their democratic possibilities of influence, the citizen's claim to democracy, 'ultimately rooted in human dignity' would lapse. ${ }^{95}$ The Court stated in a rather clear-cut manner:

Citizens must be able to defend themselves in a constitutional court against a relinquishment of competences that is incompatible with Article 79(3) of the Basic Law. The Basic Law provides for no more extensive right of challenge. (...) The defensive

${ }^{90}$ FCC OMT, supra n. 2 at para. 53.

${ }^{91}$ FCC Maastricht, supra n. 44 at paras. 62-63; FCC Lisbon, supra n. 45 at paras. 175, 211, 216 ff., 245 ff.; FCC Greece \& EFSF, supra n. 11 at para. 101; FCC ESM \& TSCG (summary review), supra n. 21 at para. 208 [EN 2014].

${ }^{92}$ A first indication may retrospectively already be identified FCC Lisbon, supra n. 45 at para. 247. However, this does not predetermine the procedural conclusions drawn in the OMT reference.

${ }^{93}$ See notably B. von Tomuschat, 'Die Europäische Union unter der Aufsicht des Bundesverfassungsgerichts', EuGRZ (1993) p. 489 et seq. and D. König, 'Das Urteil des Bundesverfassungsgerichts zum Vertrag von Maastricht', 54 Zä̈RV(1994) p. 17, 27-28.

${ }^{94}$ FCC Greece \& EFSF, supra n. 11 at paras. 101-102.

${ }^{95}$ Ibid., at para. 101. 
dimension of Article 38(1) of the Basic Law therefore takes effect in configurations in which the danger clearly exists that the competences of the present or future Bundestag will be eroded in a manner that legally or de facto makes parliamentary representation of the popular will, directed to the realisation of the political will of the citizens, impossible. The entitlement to make an application is therefore only granted if there is a substantiated submission that the right to vote may be eroded. ${ }^{96}$

The preliminary reference does not, however, provide due justification for why the Court should depart from this line in its case-law now. This weighs all the more heavily, given that this new approach potentially opens the door, as dissenting Judge Gerhardt rightly emphasizes, 'to a general right to have the laws enforced (allgemeiner Gesetzesvollziehungsanspruch)', ${ }^{97}$ a concept that has explicitly been rejected by the FCC. ${ }^{9}$ Taking the OMT reference at face value, any person eligible to vote could now challenge various actions by EU institutions before the German Federal Constitutional Court, not least because an effective limitation of the actio popularis is lacking also with regard to the condition of manifestness. ${ }^{99}$ It is hard to imagine that this is actually what the Court had in mind. The reference itself presents the central counterargument: the right to vote 'does not serve to monitor the content of democratic processes, but is intended to facilitate them'. ${ }^{100}$

Do extraordinary circumstances justify extraordinary legal remedies then? In the absence of substantive arguments it remains open to speculation why the FCC deemed it necessary to depart from its previous case-law. Meanwhile the dissenting opinion of Judge Gerhardt proves to be illuminating in this respect. It provides a critical insider's perspective on the reasoning and the motives of the majority of the Second Senate. According to Judge Gerhardt, the majority within the Senate essentially intended

to deal with the particular situation that the European Central bank has sufficient democratic legitimation only for its core obligations (...) and that therefore, if it acts outside this area, this happens without connection to the democratic formation of opinions; the Senate holds that the curtailment of the citizen's right to democratic participation comes close to a violation of identity, and it must therefore be possible to be countered by the citizens with the help of the Federal Constitutional Court; according to the Senate, it cannot be conveyed to the citizens that given such a

${ }^{96}$ Ibid., at paras. 101-102, emphasis added.

${ }^{97}$ Diss. opinion Gerhardt, supra n. 77 at para. 6. Critically also Mayer, supra n. 62 at p. 136; Heun, supra n. 76, p. 332; Schneider, supra n. 86, p. 222-223.

${ }^{98}$ FCC ESM \& TSCG (summary review), supra n. 21 at para. 199 [EN 2014], confirmed in FCC ESM \& TSCG (principal proceedings), supra n. 28 at para. 130.

${ }^{99}$ Compare in this sense also diss. opinion Gerhardt, supra n. 77 at para. 7.

${ }^{100}$ FCC OMT, supra n. 2 at para. 52 as well as previously para. 19. 
democratic deficit, and with a view to the possible significance of the OMT Decision, there is no legal protection. ${ }^{101}$

The majority's apparent assumption that citizens would have to be granted legal protection in the face of a dramatic democratic deficit at EU level ('since nobody else is around') is, however, not convincing on several accounts.

\section{Sentenced to debate}

According to the Federal Constitutional Court, acts of EU institutions are subject to ultra vires review only insofar as these acts provide the basis of actions taken by German authorities'. ${ }^{102}$ In its decision of 2011, the Court rejected as inadmissible the constitutional complaints directed against the purchases of government bonds by the ECB within the framework of its SMP programme. These acts were no sovereign acts of German public authority and could therefore, according to the Court, not be challenged by the complainants -'notwithstanding other possibilities of review. ${ }^{103}$

\section{Taking responsibility for integration by means of an open-ended debate?}

But how did the Court arrive at the conclusion that constitutional complaints against real purchases of government bonds by the ECB within the framework of SMP are inadmissible, whereas constitutional complaints against the mere announcement to buy government bonds within the framework of OMT are admissible? Firstly, unlike the decision of 2011, the OMT case is also based on inter-institutional proceedings and not only constitutional complaints. Secondly, and more importantly, the Court (re)interprets the applications in the sense that they are also directed against the inactivity of German state institutions. ${ }^{104}$ Hence, the OMT programme is, technically speaking, indirectly subject to review. ${ }^{105} \mathrm{In}$ other words, in the eyes of the Court the applications are directed both against the participation of the German Federal Central Bank (Bundesbank) in a potential (but unlikely) implementation of the OMT programme, but also against an un-

${ }^{101}$ Diss. opinion Gerhardt, supra n. 77 at para. 10.

${ }^{102}$ FCC OMT, supra n. 2 at para. 23.

${ }^{103}$ FCC Greece \& EFSF, supra n. 11 at para. 116 with reference to Maastricht and Honeywell. Critically on that M. Nettesheim, 'Euro-Rettung und Grundgesetz', EuR (2011) p. 765, 770; Thym, JZ (2011), p. 1011.

${ }^{104}$ See the critique of diss. opinion Lübbe-Wolff, supra n. 1 at paras. 2 and 22.

${ }^{105}$ Cf. D. Murswiek, 'ECB, ECJ, Democracy, and the Constitutional Court', 15 GLJ (2014) p. $147,156-157$. 
constitutional inactivity of the parliament and government. ${ }^{106}$ In the words of the FCC 'the German Bundestag and the Federal Government may not simply let a manifest or structurally significant usurpation of sovereign powers by European Union organs take place. ${ }^{107}$ A citizen could 'therefore demand that the Bundestag and the Federal Government actively deal with the question of how the distribution of powers entailed in the treaties can be restored, and that they decide which options they want to use to pursue this goal'. ${ }^{108}$

As both dissenting opinions point out, this is a highly questionable approach from a constitutional law perspective. It ultimately leads to the situation that the Bundestag is sentenced to debate by the Bundesverfassungsgericht. ${ }^{109}$ The responsibility for integration ${ }^{110}$ by means of parliamentary consent is thus joined by a hazy responsibility for integration by means of an open-ended debate.

\section{Lack of legal determination}

The first objection in this respect relates to the lack of legal determination. In the present context the (political) reactions to the alleged ultra vires act cannot sufficiently be defined in legal terms, ${ }^{111}$ as demonstrated by the following question: what would happen if the Federal Constitutional Court actually considered the OMT programme to be ultra vires in its final judgment? The Court could prohibit the Bundesbank from participating in a future implementation of the OMT programme, ${ }^{112}$ which would be a rather ineffective way of preventing the alleged ultra vires act. ${ }^{113}$ However, the Court would not be able to sufficiently determine in terms of constitutional law how parliament and government should 'deal' with the alleged breach of competences. ${ }^{114}$ Not surprisingly, the Court's statements in this respect are rather vague. In case that the alleged transgression of compe-

${ }^{106}$ FCC OMT, supra n. 2 at paras. 1 and 45 et seq. In FCC Greece \& EFSF, supra n. 11 at paras. 114-116 even acts of active participation were regarded as not being challengeable.

${ }^{107}$ FCC OMT, supra n. 2 at para. 46, emphasis added.

${ }^{108}$ Ibid., at para. 53, emphasis added.

${ }^{109}$ Diss. opinion Lübbe-Wolff, supra n. 1 at para. 22.

${ }^{110}$ For a detailed assessment of this concept, see U. Hufeld, in Andreas von Arnauld and Ulrich Hufeld (eds.), Systematischer Kommentar zu den Lissabon-Begleitgesetzen (2011) p. 25, 33-35.

${ }^{111}$ This is the core argument of diss. opinion opinion Lübbe-Wolff, supra n. 1 at paras. 12-27.

${ }^{112}$ FCC OMT, supra n. 2 at para. 45.

${ }^{113}$ The Bundesbank alone would not be able to prevent the implementation in the ECB's Governing Council (the Bundesbank's president had voted against OMT anyway). Furthermore it is questionable whether the Bundesbank would actually comply with such a judgment of the FCC, given the Bundesbank's independence vis-à-vis domestic institutions under Art. 130 para. 1 TFEU. If the FCC prohibited participation in the implementation of the OMT program, the Bundesbank would thus be faced with a conflict of laws, cf. Mayer, supra n. 62 at p. 127 et seq. and Thiele, supra n. 76 at p. 249.

${ }^{114}$ In detail diss. opinion Lübbe-Wolff, supra n. 1 at paras. 12-27. 
tences could not be legitimated expost by means of a treaty revision and a domestic statute of approval (within the limits of the eternity clause), the Bundestag and the federal government would be obliged to take either 'legal or political means' towards an annulment of the ultra vires act or 'adequate precautions' towards a minimization of domestic effects should the ultra vires act endure. This is as concrete as it gets.

Can there be a justiciable individual right to demand an open-ended debate in parliament or to request more or less ineffective actions by state organs? It is far from surprising that the Second Senate acts in contradiction to its previous caselaw ${ }^{115}$ when it recognizes such a 'claim on the merits' (Tätigwerden dem Grunde nach). ${ }^{116}$ Until now, constitutional complaints directed against the inactivity of state organs were only admissible when the omitted act could be adequately specified. ${ }^{117}$ In case of OMT, however, the selection and specification of different courses of action lies within the discretionary power of parliament and government, a fact that has to be accepted by citizens and the Federal Constitutional Court alike. $^{118}$

\section{In the name of democracy?}

The second principal objection relates to the circumvention of the democratic process. The fact that an individual voter shall be entitled to demand a more or less unspecified action by the parliament with the help of the Federal Constitutional Court and on the basis of his or her right to vote alone (i.e., beyond the means provided in the constitution, such as a petition) is incompatible with the principle of representative democracy under German constitutional law. ${ }^{119}$

Judge Gerhardt's dissenting opinion suggests that the majority within the Second Senate was ultimately concerned with ensuring the public nature of the parliamentary process. ${ }^{120}$ This observation, made from a critical internal perspective, matches with the outsider's impression: the German Federal Constitutional Court's jurisprudence on European integration seems also to be an attempt to give the floor to political positions that might otherwise remain underrepresented due to a rather strong culture of consensus among the major political parties in Ger-

${ }^{115}$ Diss. opinion Lübbe-Wolff, supra n. 1 at para. 18.

${ }^{116}$ Diss. opinion Gerhardt, supra n. 77 at para. 19.

${ }^{117}$ In particular FCC Greece \& EFSF, supran. 11 at para. 118: 'An omission on the part of the legislature may be the subject of a constitutional complaint if the complainant can rely on an express mandate of the Basic Law which essentially defines the content and scope of the duty to legislate.' For more references see opinion Lübbe-Wolff, supra n. 1 at para. 18.

${ }^{118}$ Diss. opinion Gerhardt, supra n. 77 at paras. 11, 15, 18 as well as diss. opinion Lübbe-Wolff, supra n. 1 at para. 12.

${ }^{119}$ Diss. opinion Gerhardt, supra n. 77 at para. 21.

${ }^{120}$ Ibid., para. 20. 
many with regard to EU affairs. Seen in this light, the EU related case-law of the Court aims to take the discussion (back) into the pluralistic 'publicness' of the parliament, which bears the responsibility for integration. Ultimately, the Court might even bring in the constituting power of 'the people' to decide on a new constitution. ${ }^{121}$

As a matter of fact, the Court's approach goes beyond the mere aim of securing the public nature of the parliamentary process. Rather, the courtroom in Karlsruhe itself becomes a substitute (or competitor) for the political arena. In the academic writings of a present member of the Second Senate this function of the case-law is referred to as a specific mode of 'democratic compensation or valve'. ${ }^{122}$ Some scholars even conceive of the actio popularis before the FCC as a 'constitutional-complaint-plebiscite, i.e., as a functional surrogate for the lack of direct democracy at the federal level in Germany. ${ }^{123}$ Seen from this angle, the rather increased willingness of the Bundesverfassungsgericht to adjudicate in questions of European integration presents itself as an attempt to 'de-elitify' Europe and bring it closer to the citizen.

However, it may be doubted whether a constitutional court is capable of doing so, both institutionally and structurally. Decision-making within the Federal Constitutional Court depends on legal deliberations based on reason within a panel of eight judges (admittedly elitist in its own way), not on a majority decision of the elected representatives of the people or the people themselves on the basis of political opinions developed in a pluralistic society. Interests that are defended in a courtroom have to be defended according to legal categories and therefore do not necessarily reflect political antagonisms.

There are also objections relating to the normative foundation of the 'surrogate claim' as well as the apparently underlying theory of democracy. How can the deliberate absence of plebiscitary elements in the constitution be construed as a deficit without applying a normative standard beyond this constitution? ${ }^{124}$ Can such a standard provide a sufficient normative foundation for a constitutional court to introduce an actio popularis which can ultimately turn out to have an antiparliamentarian tendency? Does the political consensus amongst the leading po-

${ }^{121}$ However, not in case of OMT. For the scenario of a new constitution see FCC Lisbon, supra n. 45 at paras. 179 and 263. For an in-depth assessment of the problem, cf. M. Nettesheim, 'Wo „endet“ das Grundgesetz?', 51 Der Staat (2012) p. 313, 337 et seq.

${ }^{122}$ P.M. Huber, in H. von Mangoldt et al. (eds.), GG Kommentar, 6th edn (2010) Art. 19 IV GG, para. 350: 'demokratiespezifische Ventil- oder Kompensationsfunktion'.

${ }^{123}$ W. Kahl, 'Bewältigung der Staatsschuldenkrise unter Kontrolle des Bundesverfassungsgerichts', DVBl. (2013) p. 197, 207.

${ }^{124}$ Accordingly, Kahl, supra n. 123 at p. 207 does not refer to the Basic Law but to its personal estimation that the absence of plebiscitary elements is no longer seasonable, especially as regards fundamental questions of European integration. 
litical parties in Germany on the 'big questions' of EU policy really amount to a democratic deficit? Would such a deficit be resolved if there were more Eurosceptic MPs in the Bundestag? Has the EU become more democratic on 25 May 2014 because a larger number of Eurosceptic MEPs have been elected?

The Court cannot possibly have meant this either. But if this is so and specific constitutional standards are not available, the alleged 'inactivity' of the Bundestag and federal government has to be accepted as an expression of a democratic majority decision. As Judge Gerhardt aptly put it:

If (...) the Federal Government approves the OMT programme and makes it one of the foundations of its own acts, and if the German Bundestag accepts all this with open eyes - against the backdrop of an intensive public debate, after having heard the President of the European Central Bank, and, according to the information provided by a member of the Budget Committee in the oral hearing, on the basis of the Bundestag's observation and assessment of the acts of the European Central Bank - this is the exercise of its democratic responsibility. The Bundestag could readily have criticised the OMT Decision by political means, threatened, if necessary, to bring proceedings for annulment before the Court of Justice of the European Union, waited for the reactions of the European Central Bank and the financial markets and then taken further steps. The fact that it did none of this does not indicate a democratic deficit, but is an expression of its majority decision for a certain policy when handling the sovereign debt crisis in the euro currency area. ${ }^{125}$

Finally, questions arise as to how far the FCC's decisions can be considered legitimate from an overall European perspective, given their potential external effects. In the words of Judge Lübbe-Wolff:

That some few independent German judges - invoking the German interpretation of the principle of democracy, the limits of admissible competences of the ECB following from this interpretation, and our reading of Art. 123 et seq. TFEU - make a decision with incalculable consequences for the operating currency of the euro zone and the national economies depending on it appears as an anomaly of questionable democratic character. ${ }^{126}$

\section{Identity review: two identities?}

The OMT reference also contains several important remarks on the modalities of the so-called identity review. For the time period following the decision of the ECJ, the Federal Constitutional Court reserves the right to review whether the

\footnotetext{
${ }^{125}$ FCC OMT, supra n. 2 at para. 23, emphasis added.
}

${ }^{126}$ Diss. opinion Lübbe-Wolff, supra n. 1 at para. 18. 
OMT programme - in its interpretation by the ECJ - violates the identity of the constitution as protected by Article 79(3) GG. ${ }^{127}$

In its judgment of 7 September 2011, the Bundesverfassungsgericht held that the essence of the principle of democracy as part of the constitutional identity would be violated if the Bundestag relinquished its 'parliamentary budget responsibility' by giving up the capability to decide on the budget on its own terms. ${ }^{128}$ According to the Court, 'no permanent mechanisms may be created under international treaties which are tantamount to accepting liability for decisions by free will of other states, above all if they entail consequences which are hard to calculate. ${ }^{129}$ While the Court states that it is not foreseeable at present whether the budgetary autonomy of the German parliament could be affected by possible losses inflicted on the Bundesbank by the OMT programme, ${ }^{130}$ it claims a right to review in two respects: an identity review of the OMT programme in its entirety on the basis of an interpretation by the ECJ on the one hand ${ }^{131}$ and a possible future identity review of single implementation measures on the other hand. ${ }^{132}$

As regards the second scenario, the Court announced that it would carry out the identity review(s) without submitting a further preliminary question to the ECJ. ${ }^{133}$ From the Federal Constitutional Court's point of view, the 'relationship of cooperation' between Luxembourg and Karlsruhe finds expression in the following separation of judicial tasks: while it is for the ECJ to interpret the legal measures taken at EU level, it rests with the FCC to determine what German constitutional identity requires and whether it has been violated. ${ }^{134}$ According to this train of thought, submitting preliminary questions to the ECJ on implementation measures would not be necessary since the ECJ would have already taken its decision on the interpretation of the OMT Decision in its entirety.

The absence of a further reference does not cause a major problem for the Federal Constitutional Court, given that it highlights the differences between the protection of national (constitutional) identity at the national and at EU level. Whereas in the context of the Lisbon judgment the Court still emphasized that national constitutional and European legal protection of national constitutional

${ }^{127}$ The legal consequences of such a decision, i.e., the declaration that the OMT programme must not produce legal consequences for any German state organ, would also be rather inefficient.

${ }^{128}$ FCC Greece \& EFSF, supra n. 11 at paras. 120 et seq.

${ }^{129}$ Ibid., at para. 128 as well as FCC ESM \& TSCG (summary review), supra n. 21 at para. 214 [EN 2014], both judgments referred to by FCC OMT, supra n. 2 at paras. 28, 102.

${ }^{130}$ FCC OMT, supra n. 2 at para. 102.

${ }^{131}$ Ibid.

${ }^{132}$ Ibid., para. 103.

${ }^{133}$ For further criticism see Mayer, supra n. 62 at p. 131.

${ }^{134}$ FCC OMT, supra n. 2 at para. 27. 
identity 'go hand-in-hand in the European legal area', ${ }^{135}$ it now draws a clear conceptual distinction between the notion of constitutional identity under Article 79(3) GG and the notion of national (constitutional) identity under Article 4(2), first sentence, TEU. The scope of the latter would not only be broader than the core protected by the former, as demonstrated exemplarily by the Sayn-Wittgenstein decision. ${ }^{136}$ According to the FCC, the two concepts also differ 'fundamentally': while the protection of identity under EU law is relative and can be subjected to for instance a proportionality review, the very essence of the principles protected under Article 79(3) GG must not be weighed up against other principles (Abwägungsfestigkeit). ${ }^{137}$ In other words, the FCC deems the protection of national identity provided by the Court of Justice inadequate in terms of national constitutional law. Two types of identity, two types of review.

However, this does not yet make obtaining a preliminary ruling from the ECJ superfluous. ${ }^{138}$ Certainly, the EU's obligation to respect the national identities, inherent in their fundamental political and constitutional structures (Article 4(2), first sentence TEU) cannot mean that legal interests linked to national identities automatically take precedence over legal interests protected by EU law. Otherwise EU law would potentially be subject to 28 identity caveats. But still Article 4(2), first sentence, TEU is a legal mechanism by means of which EU law is made permeable to certain principles of national constitutional law. ${ }^{139}$ Although conceptually obscure ${ }^{140}$ and subject to considerable differences from one country to another, ${ }^{141}$ the term 'identity' as referred to in Article 4(2), first sentence, TEU connects EU law with national constitutional law, a fact not least mirrored by several constitutional courts that have picked up on this term in their EU related case-law. ${ }^{142}$

${ }^{135}$ FCC Lisbon, supra n. 45 at para. 240. This ultimately refers to the idea that Art. 4(2), first sentence, TEU only declaratively mirrors the national constitutional foundation of EU law and the right of member states to unilaterally derogate from it in exceptional cases.

${ }^{136}$ FCC OMT, supra n. 2 at para. 29 in reference to ECJ, Case C-208/09 Sayn-Wittgenstein, judgment of 22 Oct. 2010.

${ }^{137}$ FCC OMT, supra n. 2 at para. 29.

${ }^{138}$ See also M. Kumm, 'Rebel Without a Good Cause', 15 GLJ (2014) p. 203, 209-210.

${ }^{139}$ More specifically Wendel, supra n. 46 at p. 572 et seq.

${ }^{140}$ Compare already A. von Bogdandy, 'Europäische und nationale Identität: Integration durch Verfassungsrecht?', 62 VVDStRL (2003) p. 156, 164.

${ }^{141}$ J.H. Reestman, 'The Franco-German Constitutional Divide', 5 EuConst (2009) p. 374 et seq.; M. Walter, 'Integrationsgrenze Verfassungsidentität', 72 ZaöRV (2012) p. 177, 179 et seq., both with specific regard to France and Germany.

${ }^{142}$ French Conseil constitutionnel, Case 2004-505 DC Constitutional Treaty, decision of 19 Nov. 2004, para. 13 and Case 2006-540 DC Information society, decision of 27 July 2006, para. 19; Spanish Constitutional Tribunal, Case no. 1/2004 Constitutional Treaty, decision of 13 Dec. 2004; Czech Constitutional Court, Case Pl ÚS 19/08 Treaty of Lisbon I, judgment of 26. Nov. 2008, para. 120 and Case Pl. ÚS 29/09 Treaty of Lisbon II, judgment of 3. Nov. 2009, 
An appropriate protection of national constitutional identity at EU level aims to safeguard diversity and thus presumes an autonomous definition of constitutional identity at the national level. ${ }^{143}$ This is why national constitutional courts can play a key role in the protection of national identity under EU law, as far as they are called upon to specify what 'constitutional identity' means, respectively. ${ }^{144}$ While EU law refers back to national law with regard to the substance of constitutional identity, it nevertheless regulates the legal consequences of the identity argument' under EU law. In other words, while national bodies, in particular constitutional courts, may concretize what falls under the term of constitutional identity, the Court of Justice decides to what extent the obligation to protect national constitutional identity prevails over (hypothetically) conflicting principles of EU law. Accordingly Article 4(2) first sentence, TEU can be understood as an auto-limitative mechanism by means of which EU law revokes - to some, and certainly not to an unlimited, extent - its own claim to primacy within its scope of application. ${ }^{145}$

Until today the ECJ has been particularly sensitive to concerns raised in this respect at the national constitutional level. This is especially true with regard to the concept of human dignity as defended particularly in Germany. ${ }^{146}$ The fact that constitutional assets such as the abolition of the nobility or the protection of a national official language have not only been considered legitimate interests but ultimately to outweigh other interests under EU law, ${ }^{147}$ also speaks for and not against the effectiveness of the identity review at EU level. This remedy must therefore be exhausted before taking any other measures that might end up questioning the uniform application of EU law.

para. 150; Latvian Constitutional Court, Case 2008-35-01 Treaty of Lisbon, judgment of 7 April 2009, part 16.3; Hungarian Constitutional Court, Case 143/2010 Treaty of Lisbon, judgment of 12 July 2010, part III.1; Polish Constitutional Tribunal, Case K 32/09 Treaty of Lisbon, judgment of 24 Nov. 2010, part III.2.1, III.3.8.

${ }^{143}$ Wendel, supra n. 46 at p. 573-575 and 579-581.

${ }^{144}$ Within the boundaries of the separation of powers at domestic level.

${ }^{145}$ Compare F. Mayer, 'Verfassungsgerichtsbarkeit', in A. von Bogdandy and J. Bast (eds.), Europäisches Verfassungsrecht, 2nd edn (2009) p. 559, 588-589 as well as, in detail, A. von Bogdandy and S. Schill, 'Overcoming Absolute Primacy: Respect for National Identity under the Lisbon Treaty', 48 CMLRev. (2011) p. 1417, 1432. For a stronger accentuation of the ECJ's authority of interpretation regarding the notion of national identity, however, see M. Claes, 'Negotiating Constitutional Identity or Whose Identity Is It Anyway?', in D. Anagnostou and M. Claes et al. (eds.), Constitutional Conversations in Europe (Cambridge, 2012) p. 205, 207 et seq. Accentuating the ordinary function of the identity clause B. Gustaferro, 'Beyond the Exceptionalism of Constitutional Conflicts', Jean Monnet Working Paper 01/12, p. 34 et seq.

${ }^{146}$ ECJ, Case C-36/02 Omega, judgment of 14 Oct. 2004, paras. 32 et seq. This judgment cannot be understood in a way that the ECJ would generally weigh up human dignity against the free movement of services.

${ }^{147}$ ECJ, Case C-208/09 Sayn-Wittgenstein, judgment of 22 Dec. 2010, paras. $83 \mathrm{ff}$., as well as ECJ, Case C-391/09 Runevič-Vardyn, judgment of 12 May 2011, paras. 86 et seq. 
To sum up, in case of an alleged violation of national identity, the ECJ has to be granted the opportunity to assess whether the issue at hand is compatible with Article 4(2), first sentence, TEU. This not only flows from the principle of loyalty under EU law (Article 4(3) TEU) but also from the principle of openness towards European law under national (here: German) constitutional law. Domestic identity review should, if at all, only become an option of last resort in case of a lack of protection at EU level. Even in case a future implementation of the OMT programme would violate Germany's constitutional identity, which currently seems unimaginable in any case (after all the FCC itself leaves this question open, and for good reason), the Federal Constitutional Court would still have to submit a preliminary reference to the Court of Justice. ${ }^{148}$

\section{EU LAW PERSPECTIVE AND LUXEMBOURG'S RANGE OF OPTIONS}

The preliminary reference also raises several critical questions in terms of EU law.

Procedural questions

There are already doubts as to whether the preliminary reference is admissible.

\section{Subject of reference}

Can a decision that was communicated via press release only ${ }^{149}$ and that merely prescribes a rather abstract framework for a hypothetical purchase of government bonds be subject to a preliminary ruling? Following the ECJ's case-law, one might still suppose that it could. Article 267(1)(b) TFEU generally applies to 'acts of the institutions, bodies, offices or agencies of the Union' and is kept deliberately broad compared to other provisions, e.g. Article 263(1), first sentence, TFEU. Furthermore, in order to fall within the scope of application of Article 267(1)(b) TFEU, acts neither have to be legally binding nor directly applicable according to the ECJ's case-law. ${ }^{150}$ Only if one were inclined to follow the argument according to which Article 267(1)(b) TFEU would not cover mere preparatory measures, ${ }^{151}$

${ }^{148}$ The ECJ may already comment on Art. 4(2), first sentence, TEU within the framework of the pending legal proceedings. However, a statement would necessarily remain vague due to the lack of any concrete implementation of the OMT programme so far.

${ }^{149}$ There is no other written account of this decision, compare supra n. 3.

${ }^{150}$ ECJ, Case C-322/88 Grimaldi, judgment of 13 Dec. 1989, para. 8: 'without exception'. Previously, at least implicitly, ECJ, Case 9/73 Schlüter, judgment of 8 Oct. 1973, paras. 38, 40 (decision by the Council), as well as Case 113/75 Frecassetti, judgment of 15 June 1976, paras. 8-9 (recommendation by the Commission).

${ }^{151}$ See B.W. Wegener, in Ch. Calliess and M. Ruffert (eds.), EUVIAEUV, 4th edn (2011), Art. 267 TFEU, para. 9 and M. Pechstein, EU-Prozessrecht, 4th edn (2011), para. 772. 
the OMT programme would appear to be an inappropriate subject for a preliminary decision. However, the ECJ's case-law suggests that Luxembourg will not exclude preparatory measures as such. Besides, the Federal Constitutional Court saw the (potential) problem and formulated an alternative set of questions which addresses the interpretation of the relevant primary law in an abstract way in order to meet the conditions of Article 267(1)(a) TFEU on all accounts. ${ }^{152}$ In the eyes of the FCC, such abstract interpretation by the ECJ would also be necessary for the case at hand because the FCC considers itself obliged to provide interim legal protection. ${ }^{153}$

\section{Necessity and probibition of functional misuse}

However, it is highly questionable that the preliminary questions can be considered 'necessary' in the sense of Article 267(1) TFEU and that they do not end up being a forbidden misuse of the preliminary reference procedure. Certainly, the case-law of the ECJ leaves a wide margin of discretion for domestic courts in order to determine whether or not the interpretation of EU law is necessary for the national case at hand. ${ }^{154}$ There is a general presumption of necessity that can only be rebutted in exceptional cases, ${ }^{155}$ in particular

where it is quite obvious that the interpretation which is sought of the provisions of Union law referred to in the questions bears no relation to the actual facts of the main action or to its purpose or where the problem is hypothetical or the Court does not have before it the factual or legal material necessary to give a useful answer to the questions submitted to it. ${ }^{156}$

The ECJ has been very cautious in affirming such exceptional cases, ${ }^{157}$ as also demonstrated in Pringle, even though some of the questions submitted by the Irish Supreme Court were rejected as inadmissible. ${ }^{158}$

While the ECJ's jurisprudence clearly does not aim to declare preliminary questions inadmissible only because of procedural peculiarities at the national

${ }^{152}$ FCC OMT, supra n. 2, set of questions 2.

${ }^{153}$ Ibid., para. 101.

${ }^{154}$ For the first time rudimentary in ECJ, Case 83/78 Pigs Marketing Board, judgment of 29 Nov. 1978, para. 25. With reference to a national constitutional court ECJ, Case C-399/11 Melloni, judgment of 26 Feb. 2013, paras. 28-29.

${ }^{155}$ Classic ECJ, Case 244/80 Foglia/Novello II, judgment of 16 Dec. 1981, paras. 16-21.

${ }^{156}$ See, amongst others, ECJ, Case C-467/05 Dell'Orto, judgment of 28 June 2007, para. 40; Case C-379/98 PreussenElektra, judgment of 13 March 2001, paras. 38-39. For the different categories of cases cf. P. Craig and G. de Búrca, EU Law, 5th edn (2011) p. 467 et seq.

${ }^{157}$ For one of the rare examples see ECJ, Case C-83/91 Meilicke, judgment of 16 June 1992, paras. 30-31.

${ }^{158}$ ECJ Pringle, supra n. 30 at paras. 86 et seq. 
level, it is essentially based on the telos to interdict the functional misuse of the preliminary reference procedure. ${ }^{159}$ The court stated:

Whilst the spirit of cooperation which must govern the performance of the duties assigned by Article [267] to the national courts on the one hand and the Court of Justice on the other hand requires the latter to have regard to the national court's proper responsibilities, it implies at the same time that the national court, in the use which it makes of the facilities provided by Article [267], should have regard to the proper function of the Court of Justice in this field. ${ }^{160}$

The proper function of the court in the context of a preliminary ruling consists, however, first and foremost in ensuring the uniform interpretation and application of EU law within the Union. ${ }^{161}$ This is also the reason why the competence to declare acts of the EU institutions invalid is attributed to the Court of Justice alone. ${ }^{162}$ This centralization of the competence to interpret and, if necessary, invalidate EU law is one of the central pillars of the EU's legal system and has articulately and consistently been defended by the ECJ, particularly against national constitutional courts. ${ }^{163}$

The ultra vires review carried out by the German Federal Constitutional Court, however, precisely undermines this core function. To declare the OMT reference admissible in terms of Article 267 TFEU is therefore not only problematic because Karlsruhe's pretention to have a final say on the matter makes the requested interpretation by the ECJ appear potentially irrelevant and therefore unnecessary. ${ }^{164}$ Rather, the reference seems to be an abusive request for a preliminary decision insofar as it raises doubts about Karlsruhe's willingness to accept Luxembourg's monopoly of interpretation as regards EU law. But still, submitting a reference is preferable to disregarding Honeywell and carrying out an ultra vires review without a reference. If one accepts the highly questionable premise that the applications before the FCC can be declared admissible in terms of constitutional law and that the FCC has the constitutional mandate to carry out an ultra vires review, submitting a preliminary reference to the Court of Justice appears to be the less invasive solution. However, both alternatives conceptually undermine the unity of EU law.

${ }^{159}$ ECJ Foglia/Novello II, supra n. 155 at para. 18; ECJ, Case C-231/89 Gmurzynska-Bscher, judgment of 8 Nov. 1990, para. 23.

${ }^{160}$ ECJ Foglia/Novello II, supra n. 155 at para. 20, emphasis added.

${ }^{161}$ Particularly distinct ECJ, Opinion 1/09 Patents Court, Opinion of 8 March 2011, para. 83.

${ }^{162}$ ECJ, Case 314/85 Foto Frost, 22 Oct. 1987, paras. 15 et seq.

${ }^{163}$ In recent times ECJ, Joint Cases C-188/10 and C-189/10 Melki et al., judgment of 22 June 2010, para. 54. See also A. Pliakos and G. Anagnostaras, 'Blind Date between Familiar Strangers', 15 GLJ (2014) p. 369, 376-377.

${ }^{164}$ Diss. opinion Lübbe-Wolff, supra n. 1 at para. 11; see Pernice, supra n. 82. 
Should Luxembourg declare the reference admissible in terms of Article 267 TFEU (which seems likely in political terms), it would therefore have to strictly avoid that this could be (mis)understood as a tacit approval of Karlsruhe's claimed right to carry out ultra vires reviews. Against this backdrop it would be highly surprising if the ECJ declared the reference admissible without underlining or even concretizing the limits that it has developed in its previous case-law, particularly the necessity that 'EU law is applied uniformly'. ${ }^{165}$ The ECJ would in any case have to make it crystal clear that it responds to the preliminary questions only on the premise that the referring court subsequently accepts the interpretation given by the Court of Justice. In this context the ECJ could also refer to the (admittedly ineffective) possibilities of sanctions under EU law, i.e. the infringement proceedings and state liability. Would the ECJ leave the slightest of doubt that the rules of EU constitutional law, including those regarding the ECJ's monopoly of interpretation, are to be respected by all actors, including the German Federal Constitutional Court, the central purpose of the preliminary reference procedure would be threatened. Such a statement of clarification would therefore not only be required in the case that the ECJ would not confirm the legal interpretation of the FCC. To avoid any semblance of an implicit approval of Karlsruhe's claim to ultra vires review, a clarification would also and particularly be necessary in case the interpretation by the ECJ partially resembled that of the FCC.

\section{The preliminary reference as a call for allegiance}

The Federal Constitutional Court confronts the ECJ with its interpretation of EU law in the style of a call for allegiance. It is not without good reason that critics have likened the preliminary reference to a dictate. ${ }^{166}$

The occasionally harsh criticism of the FCC's adjudication with regard to integration in the past few years ${ }^{167}$ is sometimes countered with the argument that the FCC has, in the end, never prevented an integration project whose constitutionality it has reviewed. If it is true, however, that the relationship between the ECJ and the national constitutional courts is not a hierarchical but rather a cooperative one, within which one-sided 'emergency breaks' are justified precisely by the fact that 'they do not ultimately have to be applied', ${ }^{168}$ then the mere fact that

${ }^{165}$ ECJ Melki et al., supra n. 163 at para. 54.

${ }^{166}$ Compare Pliakos and Anagnostaras, supra n. 163 at p. 375; Mayer, supra n. 62 at p. 119.

${ }^{167}$ See particularly D. Halberstama and Ch. Möllers, 'The German Constitutional Court Says “Ja zu Deutschland!”, 10 GLJ (2009) p. 1241; M. Nettesheim, 'Die Karlsruher Verkündigung', 1 Europarecht-Beiheft (2010) p. 101; Ch. Schönberger, 'Lisbon in Karlsruhe: Maastricht's Epigones at Sea', 10 GLJ (2009) p. 1201.

${ }^{168}$ A. Voßkuhle, 'Der europäische Verfassungsgerichtsverbund', $N V w Z$ (2010) p. 1, 3, 7. Before already I. Pernice, Das Verhältnis europäischer zu nationalen Gerichten im europäischen Verfassungsverbund (Berlin 2006) p. 53 et seq. 
a court has so far refrained from opting for such a worst-case scenario does not already make this court a cooperative one. The decisions' results are only one indicator for the capacity of national courts to engage in a multi-levelled judicial cooperation (Verbundfähigkeit), particularly because the checks and balances in such non-hierarchical systems emanate rather from mutual signals and dialogical interactions which need not necessarily be reflected in the decisions' results. In this respect it is not only about what courts say, but also how they say it. Whether or not the courts 'strike the right note' can be of significance, given the fact that the particularly obiter dicta can have important signalling effects. ${ }^{169}$ The problem of the OMT reference lies exactly in the fact that it leaves little room for either actor to overcome the issue at hand without losing face. ${ }^{170}$ That former judge Di Fabio makes the following statement in a case note cannot be regarded as a constructive contribution either: 'The European Court of Justice must not behave in the manner of a political institution, especially not with the notable curiosity that the European Court's president is Greek. ${ }^{171}$

Assessment of the OMT programme in substance

When assessing the OMT programme in substance, the Federal Constitutional Court takes a view that is highly questionable in terms of EU law and by all means not clearly preferable to other legal positions defended - which, as we have suggested, should be the decisive threshold.

\section{Transgression of the ECB's mandate - Pringle inverted}

The Court's reasoning is particularly questionable in that it argues that the OMT programme would manifestly transgress the ECB's mandate under EU primary law.

As demonstrated above, a central problem of ultra vires review lies in its hybrid review standard, leading to an idiosyncratic interpretation of EU law by the German Federal Constitutional Court and ultimately to a distorted view on the EU's order of competences through the lens of German constitutional law.

For the Court the decisive question was whether the OMT programme 'encroached upon the powers of the Member States for economic policy'. ${ }^{172}$ However, this major premise of the Court's legal assessment inverts the review standard of Pringle. In Pringle the ECJ had to decide whether member state actions to establish the ESM encroached on the exclusive competence of the Union in the area

\footnotetext{
${ }^{169}$ The critical reaction of the First Senate to the ECJ's Åkerberg jurisprudence is but an example, FCC, Case 1 BvR 1215/07 Counter-terrorism Database, judgment of 24 April 2013, para. 91.

${ }^{170}$ Cf. Bast, supra n. 75 at p. 180.

${ }^{171}$ U. Di Fabio, 'Karlsruhe Makes a Referral', 15 GLJ (2014) p. 107, 109.

${ }^{172}$ FCC OMT, supra n. 2 at para. 55 as well as paras. 33, 39 and question 1 lit. a.
} 
of monetary policy. ${ }^{173}$ This standard of review was imperative under EU law, for an exclusive competence of the EU in a certain field generally prevents member states from taking action therein, independent of whether or not the EU has already taken actions itself, Article 2(1) TFEU. ${ }^{174}$ While the ECJ is certainly to be criticized for not having explicitly referred to this article in Pringle - unlike AdvocateGeneral Kokott ${ }^{175}$ - its approach remains correct in substance. ${ }^{176}$

Meanwhile, competences of member states do not inversely produce a general pre-emptive effect vis-à-vis actions of EU organs. ${ }^{177}$ Under the Treaties the exercise of the Union's competences is not negatively limited by the category of 'exclusive' competences of Member States - the proposal of a negative catalogue of such 'exclusive' competences of EU member states was even expressly rejected during the European Convention. ${ }^{178}$ But this is where the approach of the Federal Constitutional Court is ultimately heading when it turns the premises of EU law upside-down and essentially asks whether there is an encroachment on the (alleged exclusive) competences of member states in the area of economic policy. Looking at EU law through the lens of national constitutional law, the Court thus creates a national domaine réservé, the violation of which is put on par with a manifest violation of competences. ${ }^{179}$ This reversal of premises allows the Court to hence-

${ }^{173}$ ECJ Pringle, supra n. 30 at paras. 48-63 (regarding the question if the introduction of Art. 136(3) TFEU complied with the conditions of Art. 48(6) TEU) as well as paras. 93-98 (with regard to the conclusion and ratification of the TESM by EU member states). With regard to the EU's (non-exclusive) competence in the area of the coordination of the member states' economic policies, the ECJ stated that the Treaties would 'not confer any specific power on the Union to establish a stability mechanism' like the ESM (ibid., at paras. 64-68 and 109-111).

${ }^{174}$ Cf. R. Schütze, European Constitutional Law (CUP 2012) p. 164-165.

${ }^{175}$ View (sic) by the A-G Kokott, para. 75.

${ }^{176}$ Particularly with regard to the key question whether member state actions under public international law encroach upon the EU's exclusive competence (second preliminary question in Pringle). With regard to a possible violation of Art. 48(6) TEU (first preliminary question) one could already have stated that the introduction of Art. 136(3) TFEU cannot by any means lead to a substantive alteration of the provisions relating to the Union's exclusive competence in Part I of the TFEU. Even under the (legally unconvincing) assumption that this new stipulation had more than a declarative character, it would constitute an explicit empowerment systemically foreseen by Art. 2(1) TFEU, see view (sic) of the A-G Kokott, para. 51.

${ }^{177}$ See also Bast, supra n. 75 at p. 176.

${ }^{178}$ In detail Gustaferro, supra n. 145 at p. 16 et seq. who, however, construes Art. 4(2) TEU as being close to 'a general clause on the exercise of Union competences protecting some national core responsibilities' (ibid., at p. 34). But even if one followed this reading of Art. 4(2) TEU, the field of economic policy at national level would certainly not be protected by Art. 4(2) TEU which addresses the national identities, inherent in the member states' 'fundamental structures, political and constitutional' and the 'essential State functions, including ensuring the territorial integrity of the State, maintaining law and order and safeguarding national security'.

${ }^{179}$ FCC OMT, supra n. 2 at para. 39. 
forth focus on the question whether the OMT is a 'predominantly economicpolicy act'. ${ }^{180}$

The Court's review standard thus virtually abstracts away from the actual legal base of the OMT programme, i.e., Article 18.1 ESCB-Statute. ${ }^{181}$ Article 18.1 ESCB-Statute, however, should have been the starting point for any legal review of the ECB's actions in the present context, given that this stipulation explicitly entitles the ECB to conduct open market operations - including bond purchases. Whereas Article 18.1 ESCB-Statute correspondingly plays a central role in the ECB's considerations, ${ }^{182}$ the Federal Constitutional Court refers to it rather incidentally. ${ }^{183}$ Instead, by asking whether the OMT programme is a 'predominantly economic-policy act' the Karlsruhe creates a review standard of its own, which it successfully applies thereafter.

The German Federal Constitutional Court also tries to connect its review standard to the case-law of the Court of Justice. ${ }^{184}$ For this the majority in the Second Senate recapitulates the three criteria on which the ECJ relied in Pringle when qualifying the ESM a measure of economic policy: the objectives to be attained, the instruments relied upon and the systematic link to other regulatory frameworks. ${ }^{185}$ With regard to the OMT's objectives, the Federal Constitutional Court furthermore refers to the ECJ's interpretation, according to which the objective of maintaining price stability could be clearly distinguished from that of safeguarding the stability of the euro area as a whole ${ }^{186}$ - a certainly questionable statement in terms of its alleged evidence. ${ }^{187}$ According to the ECJ a measure of economic policy cannot be classified as one of monetary policy 'for the sole reason that it may have indirect effects on the stability of the euro'. ${ }^{188}$ The Federal Constitutional Court applies this reasoning to purchases of government bonds by the ECB. Accordingly such purchases 'may not qualify as acts of monetary policy for the sole reason that they also indirectly pursue monetary policy objectives'. ${ }^{189}$ In and of itself, this conclusion does not raise objections.

However, the legal consequences that flow from this conclusion in the context of Pringle cannot be applied to the OMT case. The abstract distinction between

${ }^{180}$ Ibid., at para. 69, severely criticized by Heun, supra n. 76 at p. 333, 335.

${ }^{181}$ Again Bast, supra n. 75 at p. 175-176.

${ }^{182}$ FCC OMT, supra n. 2 at para. 11. Compare also the Monthly Bulletin of the ECB of Oct. 2012, p. 8.

${ }^{183}$ FCC OMT, supra n. 2 at paras. 55-56, 62 and 90.

${ }^{184}$ Ibid., at especially paras. 61-68, as well as para. 96.

${ }^{185}$ Ibid., at para. 63.

${ }^{186}$ ECJ Pringle, supra n. 30 at para. 56 (referred to by FCC OMT, supra n. 2 at para. 64).

${ }^{187}$ Compare the case note of Ruffert, $J Z$ (2013) p. 257 (who approves the ECJ's approach in an overall view).

${ }^{188}$ ECJ Pringle, supra n. 30 at paras. 56 and 97.

${ }^{189}$ FCC OMT, supra n. 2 at para. 64. 
economic and monetary policy in terms of policy fields had direct legal consequences in Pringle because the ECJ had to assess whether actions taken by EU member states under international law encroached upon the exclusive competence of the Union in the field of monetary policy, as laid down abstractly in Article 3(1) (c) TFEU. Whereas Pringle thus concerned the compliance of external member state actions with the pre-emptive effect of an exclusive EU competence in a certain (abstract) policy field, ${ }^{190}$ the OMT ruling concerns the review of an act of an $E U$ institution taken on the basis of a concrete legal basis of primary law. In such a scenario legal review must necessarily start from the relevant legal base.

Article 18.1 ESCB-Statue entitles the ECB to use certain specified instruments without distinguishing whether these instruments are primarily to be qualified as measures of economic or monetary policy. Instead Article 18.1 ESCB-Statute allows the ECB to conduct open market operations in order 'to achieve the objectives of the ESCB and to carry out its tasks'. The primary objective of the European System of Central Banks (ESCB) is undoubtedly the maintenance of price stability, as enshrined in Article 127(1), first sentence, and Article 282(2), second sentence, TFEU. ${ }^{191}$ Without prejudice to this key objective, the ESCB shall furthermore support the general economic policies in the Union, as laid down in Article 127(1), second sentence, and Article 282(2), third sentence, TFEU.

This already demonstrates that the question of legality or illegality of an instrument of open market policy does not correlate with the (by the way contested) ${ }^{192}$ dichotomy of monetary and economic policy. Within the framework of open market operations the ECB can consequently also take action in the field of 'economic policy' as far as this serves its objectives. ${ }^{193}$ Article 18.1 ESCB-Statute thus frames the relevant question in terms of a certain finality: does the OMT programme serve the principal objective of maintaining price stability and/or does it support economic policy? The FCC on the other hand frames it in terms of a certain policy field: is the OMT programme a predominantly economic-policy act? $^{194}$

This is why the ECJ, should it declare the questions admissible, would have to precisely define the review standard under EU law and clearly distinguish the OMT case from Pringle. It would also have to repulse the claim that the question if an EU organ has violated competences can be assessed by asking whether the

\footnotetext{
${ }^{190}$ Art. 136(3) TFEU only has a declaratory effect according to the ECJ and was not yet in force when the Pringle judgment was promulgated.

${ }^{191}$ In detail A. Thiele, Das Mandat der EZB und die Krise des Euro (Mohr Siebeck 2013) p. 24 et seq.

${ }^{192}$ See M. Goldmann, 'Adjudicating Economics?', 15 GLJ (2014) p. 265, 269 et seq.

${ }^{193}$ Heun, supra n. 76 at p. 333.

${ }^{194}$ For the distinction between competences based on objectives and policy fields, see Bast, supra n. 75 at p. 175 .
} 
EU act at hand falls within a policy field for which the member states essentially remain responsible.

But even if we accepted the premise of the German Federal Constitutional Court - just for the sake of the argument and contrary to the argument just made - it is hardly convincing to classify the OMT programme as a 'predominantly economic-policy act'. The following considerations will focus only on some, albeit central arguments in this respect. ${ }^{195}$

Already the Bundesverfassungsgericht's elaborations on the OMT programme's objectives raise concerns. Explicitly referring to two Monthly Bulletins by the $\mathrm{ECB}$, the Court states that the OMT programme is meant to 'neutralise spreads on government bonds of selected Member States of the euro currency area which have emerged in the markets and which adversely affect the refinancing of these Member States. ${ }^{196}$ It is somewhat surprising that this statement cannot at all be inferred from these Bulletins, ${ }^{197}$ given that they explicitly describe OMTs as 'monetary policy instrument[s]' which 'aim at ensuring an effective transmission of the Eurosystem's monetary policy and, hereby, at securing the conditions for an effective conduct of the single monetary policy within the euro area, with a view to achieving its primary objective of maintaining price stability. ${ }^{198}$

The FCC continues to handle the assessments of the ECB in a remarkable way, given that it prioritizes the 'convincing expertise' of the Bundesbank over that of the ECB. ${ }^{199}$ This already surprises with regard to the fact that the Bundesbank is subjected to ECB instructions, ${ }^{200}$ but particularly with regard to the legal independence and specific expertise of the ECB which should necessarily entail a wide margin of discretion to be respected by the Court. ${ }^{201}$ However, the ECB's claim that the OMT programme aims to safeguard an appropriate monetary policy transmission and the singleness of the monetary policy ${ }^{202}$ is explicitly considered irrelevant by the Bundesverfassungsgericht. ${ }^{203}$ According to the majority in the Second Senate:

${ }^{195}$ For further arguments, see T. Beukers, 'In the ECB We Do Not Trust', 15 GLJ (2014) p. 343, 349 et seq. and Heun, supra n. 76 at p. 334-335.

${ }^{196}$ FCC OMT, supra n. 2 at para. 70 , emphasis added.

${ }^{197}$ For a comprehensive criticism of the FCC's practice of citation, see Heun, supra n. 76 at p. 333 et seq. with further examples.

${ }^{198}$ ECB Monthly Bulletin, Oct. 2012, p. 7. According to the Monthly Bulletin of Sept. 2012 on p. 7: 'OMTs aim at safeguarding the transmission mechanism in all euro area countries and the singleness of the monetary policy.'

${ }^{199}$ FCC OMT, supra n. 2 at para. 71.

${ }^{200}$ Compare Ch. Herrmann, 'Luxemburg, wir haben ein Problem!', EuZW (2014) p. 161, 162.

${ }^{201}$ For a detailed assessment of this problem, see Goldmann, supra n. 192, p. 266 et seq.

${ }^{202}$ Press release of 6 Sept. 2012, supra n. 3. This objective is also mentioned in FCC OMT, supra n. 2 at para. 2, 7, 95 et seq.

${ }^{203}$ Critique also by Beukers, supra n. 195 p. 348-349. 
The fact that the purchase of government bonds can, under certain conditions [also], help to support the monetary policy objectives of the European System of Central Banks does not turn the OMT Decision itself into an act of monetary policy. In this respect, it also applies vice versa what the Court of Justice has said regarding the allocation of assistance measures of the European Stability Mechanism [...]. The (economic) accuracy or plausibility of the reasons for the OMT Decision are irrelevant in this respect. ${ }^{204}$

Of course this merely 'proves' what was postulated in the first place, namely the assertion that the announced purchase of government bonds could 'under certain conditions also' (unter Umständen auch) have implications for monetary policy - in short, that its monetary character would only be of a secondary nature. However, the assessment of the programme's potential effects essentially depends on an economic evaluation. In other words, the argument which the Federal Constitutional Court derives from Pringle only works on the basis of an economic estimation that the OMT programme merely produces indirect effects on the stability of the euro'. This is exactly what the ECB denies on the basis of a sound economic assessment that the Court cannot just replace with its own economic evaluation without itself overstepping its legal mandate.

Another argument for the Bundesverfassungsgericht to qualify the OMT programme as an act falling predominantly in the field of economic policy is the fact that the ECB links the purchase of bonds to the conditionality of the macroeconomic assistance programmes. In the eyes of the Court, the OMT programme thus appears to be functionally equivalent to the ESM and the EFSF, but lacking democratic control. ${ }^{205}$ The converse argument seems more convincing, however: Precisely the fact that the European Central Bank attaches its OMT programme to the conditionality of the assistance programmes demonstrates that it does not pursue an economic policy of its own, but that it rather limits itself to the mere support of the existing economic policy in accordance with its mandate. ${ }^{206} \mathrm{By}$ referring to the macroeconomic conditions of the rescue measures, the ECB accepts political decisions which are ultimately taken by other actors (compare Article 13 TESM) and which are - and in Germany have to be $e^{207}$ - subject to parliamentary accountability. According to this interpretation it even seems neces-

${ }^{204}$ FCC OMT, supra n. 2 at para. 96, emphasis added.

${ }^{205}$ Ibid., at para. 79.

${ }^{206}$ Aptly Bast, supra n. 75 at p. 178.

${ }^{207}$ See $\$ 4$ para. 1, no. 1, 2 in conjunction with para. 2 of the German ESM Financing Act. See on the necessity of the constitutive parliamentary approval FCC ESM \& TSCG (summary review), supra n. 21 at para. 274 [EN 2014], confirmed in FCC ESM \& TSCG (principal proceedings), supra n. 28 at para. 217. For the situation in Finland, see P. Leino and J. Salminen, 'The Euro Crisis and Its Constitutional Consequences for Finland', 9 Eu Const (2013) p. 451 et seq. 
sary for the ECB to attach OMTs to the conditionality of the assistance programmes in order to act within the boundaries of its mandate.

It would not be surprising if the Court of Justice would, on the basis of a review starting from Article 18.1 ESCB-Statute and explicitly acknowledging the ECB's economic margin of appreciation, consider the OMT programme to be in accordance with the Treaties not despite but because of its attachment to the conditionality of the assistance programmes and the fact that it serves the objective of price stability according to the independent economic assessment of the ECB.

\section{Article 123 TFEU}

With view to a possible breach of Article 123 TFEU it is important to note that this provision, according to its wording, only prohibits the 'direct' purchase of debt instruments from member states by the ECB, i.e., the purchase of government bonds on the primary market.

In its summary review of 2012 the Federal Constitutional Court already noted that it considers purchases on the secondary market 'aiming at financing the Members' budgets independently of the capital markets' to be prohibited too, as they would 'circumvent the prohibition of monetary financing. ${ }^{208}$ This section is notably absent in the OMT reference. Although the Court continues to assume that Article 123 TFEU must not be circumvented by certain purchases on the secondary market, it fails to apply its own criterion of intent, i.e., the requirement that the measure at hand must have the specific purpose of financing national budgets independent from capital markets. ${ }^{209}$

In a rather abstract and general manner the Court postulates that Article 123 TFEU would not be limited to purchases on the primary market, but rather is the 'expression of a broader prohibition of monetary financing of the budget'. ${ }^{210}$ Again it is astonishing to see how the Second Senate's majority tries to back up its argument with references to external sources which do not at all underpin its argument. The three sources it cites - amongst the authors is Judge and Vice President of the ECJ, Koen Lenaerts, as well as a Member of the Legal Service of the Council, Alberto de Gregorio Merino ${ }^{211}$ - do not in fact support the majority's interpretation of Article $123 \mathrm{TFEU}$ in this respect. ${ }^{212}$

${ }^{208}$ FCC ESM \& TSCG (summary review), supra n. 21 at para. 278 [EN 2014], emphasis added.

${ }^{209}$ For this criterion see Wendel, supra n. 27 at p. 51.

${ }^{210}$ FCC OMT, supra n. 2 at para. 85.

${ }^{211}$ The FCC refers to V. Borger, 'The ESM and the European Court's Predicament in Pringle', $14 G L J$ (2013) p. 113, 119, 134; de Gregorio Merino, supra n. 34 at p. 1625 (there at footnote 36) and p. 1627; Koen Lenaerts and Piet Van Nuffel, European Union Law, 3rd edn (2011) para. 11-037.

${ }^{212}$ For harsh criticism see Heun, supra n. 76 at p. 335. Cf. also Thiele, supra n. 76 at p. 245 (there at footnote 32). 
In substance, it is convincing, however, that Article 123 TFEU does not allow the ECB to purchase government bonds on the secondary market under all circumstances. This does not result primarily from the 7 th recital of Regulation (EC) No. 3603/93, ${ }^{213}$ but rather from the rationale behind Article 123 TFEU. In this respect the Federal Constitutional Court correctly acknowledges the key role that teleological interpretation plays in the ECJ's reasoning. ${ }^{214}$ As demonstrated by the interpretation of Article 125 TFEU in Pringle, the ECJ sometimes also defines the telos in reference to a provision's genesis. ${ }^{215}$ According to the ECJ, Article 125 TFEU aims to ensure a sound budgetary policy at the national level. The article was to guarantee that the Member States remain subject to the logic of the market when they enter into debt, since that ought to prompt them to maintain budgetary discipline'. ${ }^{216}$ This is also the key goal of Article $123 \mathrm{TFEU},{ }^{217}$ an understanding similarly supported by historical evidence. ${ }^{218}$ As a matter of fact, (fiscal) budgetary discipline ultimately contributes to the maintenance of price stability as the primary (monetary) goal.

The ECJ declared the ESM to be in conformity with EU law precisely because of the ESM's strict conditionality, which would prevent the incentive of member states to conduct sound budgetary policies from being undermined. ${ }^{219}$ One may ask, of course, whether the disciplinary effects of market mechanisms can be considered functionally equivalent to the regulative effects of the reform programmes at all. ${ }^{220}$ The previous practice, namely the efforts of all countries affected to escape the rescue mechanisms as soon as possible, ${ }^{221}$ seems to prove the disciplining (if not deterrent) character of the programmes, however. ${ }^{222}$

With regard to Article 123 TFEU this also means: precisely the fact that the OMT programme is linked to the conditionality of the rescue measures speaks not against, but in favour of its conformity with EU law. It would therefore only be consistent if the ECJ - in accordance with its reading of Article 125 TFEU -

${ }^{213}$ Although this particularly addressed the national level.

${ }^{214}$ FCC OMT, supra n. 2, at paras. 85-86.

${ }^{215}$ ECJ Pringle, supra n. 30, at para. 135.

${ }^{216}$ Ibid., at para. 135.

${ }^{217}$ Compare U. Häde, 'Die europäische Währungsunion in der internationalen Finanzkrise', EuR (2010) p. 854, 856; U. Häde, in Ch. Calliess and M. Ruffert (eds.), EUVIAEUV, 4th edn (2011), Article 123 TFEU, para. 2.

${ }^{218} \mathrm{Cf}$. the EMU draft treaty referenced by the ECJ, printed in the EC Bulletin, Supplement 2/91, p. 55-56 and 58.

${ }^{219}$ ECJ Pringle, supra n. 30 at paras. 136-137 and 143.

${ }^{220}$ Aptly M. Nettesheim, 'Europarechtskonformität des Europäischen Stabilitätsmechanismus', NJW (2013) p. 14, 16.

${ }^{221}$ Like Portugal in recent times.

${ }^{222}$ Assessing the empirical effects however requires, once again, a margin of discretion a court has to respect. 
interpreted Article 123 TFEU in a way that allows for ECB purchases of government bonds on the secondary market as long as this does not interfere with price stability and the member states do not lose the incentive for having sound budgetary policies. ${ }^{223}$ Whether or not the ECJ will establish further conditions for an (unlikely) future implementation of the OMT programme is hard to predict. While it corresponds to an interpretation - rather widely accepted in the literature - that Article 123 TFEU also prohibits certain kinds of purchases on the secondary market in order to prevent a bypassing of its rationale, ${ }^{224}$ the concrete scope of such a prohibition of circumvention remains an open question so far. ${ }^{225}$ It is highly plausible, however, that it does not at any rate extend to cases in which the purchase of government bonds on the secondary market by the ECB is deemed necessary for guaranteeing the stability of the euro, as price stability necessarily presupposes the stability of the currency as a whole. ${ }^{226}$ In this light the legal interpretation of the Court that the OMT programme (manifestly!) violates Article 123 TFEU seems far from convincing. ${ }^{227}$

\section{Judicial restraint - lost?}

The defining attribute of the Federal Constitutional Court's decision on the ESM and the TSCG of 2012 was its sensitivity vis-à-vis the (national) legislature. Central parts of the decisions' ratio decidendi are shaped by techniques of judicial constraint, be it by respecting the legislature's margin of assessment, be it through

${ }^{223}$ Accordingly Thym, supra n. 31 at p. 263 and Thym and Wendel, supra n. 32 at p. 749.

${ }^{224}$ See among others A. Kämmerer, in R. Siekmann (ed.), EWU (2013) Art. 123 TFEU, paras. 23 et seq.; Thym, supra n. 31 at p. 263; Ruffert, supra n. 34 at p. 1787-1788; D. Hattenberger, in J. Schwarze (ed.), EU-Kommentar, 3rd edn (2012), Art. 123 TFEU, para. 6; R. Bandilla, in Grabitz/ Hilf/Nettesheim (eds.), Das Recht der Europäischen Union, 44th update (2011), Art. 123 TFEU, para. 9.

${ }^{225}$ Similar findings by B. Kempen, in R. Streinz (ed.), EUVIAEUV, 2nd edn (2012), Art. 123 TFEU, para. 5.

${ }^{226} \mathrm{Ch}$. Herrmann, 'Die Bewältigung der Euro-Staatsschulden-Krise an den Grenzen des deutschen und europäischen Währungsverfassungsrechts', EuZW (2012) p. 805, 811. See also Beukers, supra n. 195 at p. 360 et seq. Differently, however, FCC OMT, supra n. 2 at para. 72: 'As for the European Central Bank claiming to safeguard the current composition of the euro currency area with the OMT Decision (...), this is obviously not a task of monetary policy but one of economic policy, which remains a responsibility of the Member States. Pursuant to Art. 140 TFEU, the decisions on the composition of the euro currency area are the responsibility of the Council, the European Parliament, the Commission and the Member States.' This argument is self-contradictory, see also Bast, supra n. 75 at p. 177-178.

${ }^{227}$ For further arguments cf. Heun, supra n. 76 at p. 334. 
the application of restrictive review standards. ${ }^{228}$ The same is true for the decision on the principal proceedings of $2014 .^{229}$

Such wise caution is unfortunately lacking in the OMT reference. There is a distinct difference between the wide margin of discretion granted to the German Bundestag on the one hand and the failure to even mention any possible leeway for the ECB on the other hand. This is quite astounding given the fact that the ECB's independence both in terms of Union and national law seems to at least imply such a margin of discretion. The ECB is responsible for a dynamic and complex set of tasks where decisions are made on the basis of prognoses that require specific technical knowhow and the ability to flexibly generate (new) knowledge and strategies. This explains the calls for limiting the Court's review to a mere 'rationality check' instead of a full review. ${ }^{230}$

In terms of German constitutional law, this argument can be rooted in Article 88 , second sentence, GG, according to which the ECB is independent and committed to the overriding goal of ensuring price stability. This provision essentially legalizes the limited democratic control over ECB actions. ${ }^{231}$ In its Maastricht judgment the Federal Constitutional Court considered this new article as being a specific modification of the principle of democracy based on the assumption - which was, according to the Court, 'tried and tested in the German legal order, and also by the scientific community' - that an independent central bank is in a better position to ensure price stability than politicians. ${ }^{232}$ But if this is so, then the independence of the ECB cannot be challenged with reference to the (specifically modified) principle of democracy under constitutional law. When the Court now considers the independence of the ECB a 'divergence' from the democracy principle and assumes that the ECB's mandate would have to be 'shaped narrowly' in order 'to meet democratic requirements' ${ }^{233}$ it applies a much more restrictive approach than it did in its previous Maastricht judgment. In other words, the ECB's independence which was initially constitutionally demanded is now turned into one that is barely in conformity with the essence of the principle of democracy.

According to the Court, the boundaries of the ECB's mandate are 'fully subject to judicial review' which, as is admitted, would fall under the primary responsibil-

${ }^{228}$ FCC ESM \& TSCG (summary review), supra n. 21 at paras. 213, 217, 222, 228, 234, 271 [EN 2014]. For details see Wendel, supra n. 27 at p. 41 et seq.

${ }^{229}$ FCC ESM \& TSCG (principal proceedings), supra n. 28 at paras. 164, 173 f., 175, 181, 184 f., 216.

${ }^{230}$ Goldmann, supra n. 192, p. 266-267. See furthermore Thym, supra n. 31 at p. 263; Mayer, supra n. 62 at p. 135; Herrmann, supra n. 226 at p. 810; Kumm, supra n. 138 at p. 214; Heun, supra n. 76 at p. 336; Bast, supra n. 75 at p. 176-177.

${ }^{231}$ I. Pernice, in H. Dreier (ed.), GG, 2nd edn (2008), Art. 88 GG, para. 26.

${ }^{232}$ FCC Maastricht, supra n. 44 at para. 154, repeated in FCC OMT, supra n. 2 at para. 32.

${ }^{233}$ FCC OMT, supra n. 2 at paras. 58-59. 
ity of the Court of Justice. ${ }^{234}$ Of course German constitutional law standards are still not binding for the ECJ. This is also why the Federal Constitutional Court refers to EU case-law in order to establish that judicial review regarding the delimitation of competences would not interfere with the ECB's independence. ${ }^{235}$ The quoted judgment of the ECJ does not, however, deal with the question how intense the review powers of the Court of Justice are vis- $\grave{a}$-vis the ECB with regard to its mandate. It rather addresses the question in how far the ECB is subject to the legislative framework regulating the investigative powers of the European Anti-Fraud Office. ${ }^{236}$

A general exclusion of any margin of appreciation would certainly be inappropriate. After all, the question about the 'specific content' of the ECB's actual powers (in this respect Karlsruhe recognizes the ECB's independence) can hardly be detached from the question of the division of competences. As demonstrated above, the key point of the legal assessment, on the basis of Article 18.1 ESCBStatute, is not whether or not the OMT programme is to be considered a predominantly economic-policy act, but whether or not the OMT programme furthers the objectives of the ESCB. Evaluating the adequacy of the OMT programme with regard to this finality presupposes economic assessments and prognoses about the programme's actual effects within the framework of a highly volatile context. This does not imply, as the Federal Constitutional Court suggests, that no judicial control would be the only alternative (which it rejects); rather this is a reason to respect certain margins of appreciation for economic assessments, the boundaries of which a court can only submit to a 'rationality check'. ${ }^{237}$

When the Federal Constitutional Court openly invites the ECJ to carry out a full judicial review, the latter would be well advised to act with caution. It will be a particularly demanding task for the Court of Justice to delineate the extent of the ECB's margin of discretion, which legally emanates from its independence under Article 130 TFEU. With regard to the necessity of the decision under Article 267(1) TFEU, the question arises whether the ECJ could consider limiting its review to the question of the presence of a manifest violation, given that only such a qualified violation could be relevant within the framework of an ultra vires review. However, such an approach would certainly not create legal certainty and thus contradict the mandate of the Court under Article 19(2) TEU to uphold the rule of law in its interpretation and application of the treaties.

${ }^{234}$ Ibid., at para. 58.

${ }^{235}$ Ibid., at para. 60 .

${ }^{236}$ ECJ, Case C-11/00 Commission/ECB, judgment of 10 July 2003, para. 135. The judgment only includes an abstract statement that the ECB is generally subject to review by the Court of Justice and the Court of Auditors.

${ }^{237}$ Again Goldmann, supra n. 192, p. 266-267. 


\section{TRANSNATIONAL DIMENSION: COMPARATIVE LEGAL REASONING}

Beyond the framework of Union and national constitutional law in a narrower sense, the OMT reference as well as the ESM decision on the principal proceedings reveal an interesting transnational dimension. In both decisions the German Federal Constitutional Court relies on comparative constitutional law in order to support its argument. The Court thus confirms the EU wide phenomenon of comparative legal reasoning which contributes to a transnational dialogue between constitutional courts. 238

In its ESM decision the Second Senate makes multiple references to decisions taken by its Estonian, ${ }^{239}$ French $^{240}$ and Austrian ${ }^{241}$ counterparts. It has never made more references to foreign case-law in any other judgment before. However, as in its previous case-law, in the ESM decision the Court's comparative 'reasoning' only takes the form of selective cross-references with the aim of making the argument more compelling. The Court thus relies on an external 'persuasive authority ${ }^{242}$ that is meant to increase the persuasiveness of its own argument. Of course the open use of comparative arguments is only one apparent element of inter-judicial relations. However, as far as a court makes comparative law a deliberate part of its argument in its ratio decidendi the role of comparative reasoning cannot anymore be reduced to that of an auxiliary hermeneutic instrument or a reference to persuasive (external) authority. From a transnational perspective, comparative reasoning appears to become a mode of judicial dialogue that allows constitutional courts to engage in a European-wide process of shaping a 'new' ius publicum europae. ${ }^{243}$

With regard to the audience of comparative law arguments, the determination of common standards could certainly also be understood as a demonstration of collective opposition against the ECJ. This is a plausible understanding of what the Federal Constitutional Court does in its OMT reference when it refers to a whole range of EU-related case-law in other member states. ${ }^{244}$ According to the Court, the

${ }^{238}$ For a detailed assessment of the EU related case-law, see M. Wendel, 'Comparative Reasoning and the Making of a Common Constitutional Law', ICON(2013) p. 981 et seq. For an analysis beyond the EU related case-law see now also M. Bobek, Comparative Reasoning in European Supreme Courts (OUP 2013).

${ }^{239}$ FCC ESM \& TSCG (principal proceedings), supra n. 28 at paras. 211, 220.

${ }^{240}$ Ibid., at para. 244.

${ }^{241}$ Ibid., at paras. 188, 214, 221, 243.

${ }^{242}$ On this concept see H.P. Glenn, 'Persuasive Authority', 32 McGill Law Journal (1987) p. 261 et seq.

${ }^{243}$ For details see A. von Bogdandy and S. Hinghofer-Szalkay, 'Das etwas unheimliche Ius Publicum Europaeum', 73 Zä̈RV(2013) p. 209, 212 et seq.

${ }^{244}$ Cf. Mayer, supra n. 62 at p. 134. 
principles concerning the protection of the constitutional identity and of the limits of the transfer of sovereign powers to the European Union can also be found, with modifications depending on the existence or non-existence of unamendable elements in the respective national constitutions, in the constitutional law of many other Member States of the European Union. ${ }^{245}$

It is correct that the concept of ultra vires review has been taken up by several other courts on different occasions, namely the Danish Supreme Court, ${ }^{246}$ the Polish Constitutional Tribunal ${ }^{247}$ and the Czech Constitutional Court. ${ }^{248}$ Comparable approaches are discussed particularly in Hungarian and Estonian constitutional law. ${ }^{249}$ There are significant differences, however. Apart from the FCC only the Czech Constitutional Court has exercised an ultra vires review in judicial practice so far, ${ }^{250}$ although in the specific context of this case EU law appeared to be not the reason behind, but rather the means for carrying out a conflict between the Constitutional Court and the Supreme Administrative Court. ${ }^{251}$

With regard to the identity review, it is important to note that conceptual differences are not necessarily related to the 'existence or non-existence' of provisions that establish substantial limits on constitutional amendments as the Federal Constitutional Court suggests. The identity approach taken by the FCC is rather unique in Europe. No other constitutional court within the EU has spelled out an eternity clause in the EU context as extensively as the FCC has done. This is particularly true for the jurisprudence of the French Constitutional Council, but also for a range of other member states whose constitutions include prohibitions on constitutional amendments. ${ }^{252}$ The Czech Constitutional Court has even openly objected to the FCC's approach, a rather rare phenomenon. ${ }^{253}$

${ }^{245}$ FCC OMT, supra n. 2 at para. 30.

${ }^{246}$ Danish Highest Court, Case I 361/1997 Carlsen/Rasmussen, judgment of 6 April 1998.

${ }^{247}$ Polish Constitutional Tribunal, Case K 18/04 Treaty of Accession, judgment of 5 Nov. 2005.

${ }^{248}$ Czech Constitutional Court, Case Pl. ÚS 19/08 Treaty of Lisbon I, judgment of 26 Nov. 2008, paras. 120, 139 and 216.

${ }^{249}$ For a detailed assessment see Wendel, supra n. 46 at p. $468 \mathrm{ff}$.

${ }^{250}$ Czech Constitutional Court, Case Pl. ÚS 5/12 Slovaq Pensions, judgment of 31 Jan. 2012, part VII. See J. Komárek, 'Czech Constitutional Court Playing with Matches', EuConst (2012) p. 323 et seq.

${ }^{251}$ The dispute was ultimately resolved for other reasons. For a comprehensive assessment see M. Bobek, 'Landtová, Holubec, and the Problem of an Uncooperative Court', EuConst (2014) p. 54 et seq.

${ }^{252}$ Wendel, supra n. 46 at p. 331 et seq.

${ }^{253}$ Czech Constitutional Court, Case Pl. ÚS 29/09 Lisabon II, judgment of 3 Nov. 2009, para. 113. 


\section{OUTLOOK: WHAT ROLE FOR CONSTITUTIONAL COURTS IN PRELIMINARY RULING PROCEEDINGS?}

From an overall view the Bundesverfassungsgericht's OMT reference reveals an intrinsic paradox: In a doubtlessly well-intentioned effort to protect the principle of democracy against an alleged transgression of the ECB's mandate under the Treaties, the FCC itself exceeds the limits of its mandate under the German Basic Law. Whether or not the Court will find its way out of this difficult situation in which it has manoeuvred itself depends to a large extent on the ECJ and its handling of the OMT case. At any rate, the judges in Karlsruhe did not make it easy for their colleagues in Luxembourg.

Of all the possible scenarios ${ }^{254}$ it seems unlikely that the Court of Justice will follow the Federal Constitutional Court's reasoning in an outright way. If Luxembourg declares the preliminary questions admissible - albeit underlining its monopoly of interpretation - it seems reasonable that it will emphasize the ECB's economic margin of discretion and will allow the OMT programme under the conditions that it neither undermines price stability nor the incentive for member states to adopt sound budgetary policies. Timing also plays a crucial role. Since the ECJ is not engaging in an accelerated procedure, ${ }^{255}$ its preliminary ruling can be expected roughly in about one and a half years. The OMT programme may have already been abandoned at that stage. With regard to the danger of deflation we hear a lot about 'quantitative easing' these days. ${ }^{256}$ In case the OMT programme was put to an end, the ECJ could approach the Federal Constitutional Court with regard to a possible termination of the proceedings.

Conversely it would be remarkable if the German Federal Constitutional Court ultimately declared the OMT programme to be ultra vires and provoked an open conflict. The lack of precision and effectiveness of the legal consequences raises doubts about the sincerity of the Court's threat scenario. ${ }^{257}$ On the other hand it also diminishes the effective risk posed by declaring the OMT programme ultra vires. At any rate, Karlsruhe still has a trump up its sleeve: in the aftermath of the ECJ's decision it could apply the same standards that it developed in Honeywell specifically for the ultra vires review of ECJ adjudication. According to its own standards the Federal Constitutional Court has to respect 'the Union's own methods of justice' as well as the Court's 'right to tolerance of error'. ${ }^{258}$ It is hence

${ }^{254}$ Cf. Mayer, supra n. 62 at p.134.

${ }^{255}$ Unlike in Pringle where the Irish Supreme Court successfully demanded the accelerated procedure to be applied, see on that Fahey and Bardutzky, supra n. 14 at p. 109.

${ }^{256}$ On this Fahey and Bardutzky, supra n. 14, at p. 122.

${ }^{257}$ In this sense diss. opinion Lübbe-Wolff, supra n. 1 at para. 28.

${ }^{258}$ FCC Honeywell, supra n. 64 at para. 66. 
not a matter for the Federal Constitutional Court in questions of the interpretation of Union law which with a methodical interpretation of the statute can lead to different outcomes in the usual legal science discussion framework, to supplant the interpretation of the Court of Justice with an interpretation of its own. ${ }^{259}$

The decision of the ECJ will certainly lie within this discursive 'framework'. This gives reason to expect that an open conflict will be avoided even in case the ECJ does not follow the FCC's approach to a large extent. One may hope, nonetheless, that the OMT reference did not set a precedent for future cases.

But how could a better preliminary reference by a national constitutional court look like? What exactly could be the added value of a preliminary reference by national constitutional courts? The scholarship has paid far too little attention to this important question so far. ${ }^{260}$ Perhaps this is also due to a lack of empirical evidence. National constitutional courts have long been more than cautious to take the route to Luxembourg. However, the practice has markedly increased over the past few years. ${ }^{261}$ Constitutional courts in Austria, ${ }^{262}$ Belgium, ${ }^{263}$ Lithuania, ${ }^{264}$ Italy $^{265}$ and Spain ${ }^{266}$ as well as the French Constitutional Council ${ }^{267}$ have all referred to the ECJ in the framework of Article 267 TFEU. None of these proceedings was embedded in an ultra vires review.

Looking ahead, two fields appear to be particularly promising for preliminary references of national constitutional courts. On the one hand, they can make a contribution to safeguarding federal plurality, as demonstrated above within the context of the identity clause (Article 4(2), first sentence, TEU). On the other

${ }^{259}$ Ibid.

${ }^{260}$ But see henceforth J. Komárek, 'National constitutional courts and the European Constitutional Democracy', ICON (2014 forthcoming).

${ }^{261}$ Cf. still G. Martinico, 'Preliminary Reference and Constitutional Courts', in F. Fontanelli et al. (eds.), Shaping Rule of Law Through Dialogue (2010) p. 221, 224 et seq.

${ }^{262}$ Preliminary references led, amongst others, to Cases C-143/99 Adria-Wien Pipeline; C-171/01 Wählergruppe Gemeinsam, C-465/00 et al. Österreichischer Rundfunk; C-293/12 and C-594/12 Digital Rights et al. (Data Retention II).

${ }^{263}$ Preliminary references led, amongst others, to Cases C-93/97 Fédération belge des chambres syndicales de médecins; C-303/05 Advocaten voor de Wereld (European Arrest Warrant); Case C-305/05 Ordre des barreaux francophones et germanophone; C-212/06 Gouvernement de la Communauté française et Gouvernement wallon.

${ }^{264}$ A preliminary reference led to Case C-239/07 Sabatauskas.

${ }^{265}$ Preliminary references led to Case C-169/08 Presidente del Consiglio dei Ministri v. Regione Sardegna, cf. the case note by G. della Cananea, 'The Italian Constitutional Court and The European Court of Justice', 14 EPL (2008) p. 523 et seq., and to Case C-418/13 Napolitano et al., cf. O, Pollicino, 'From Partial to Full Dialogue with Luxembourg',10 EuConst (2014) p. 143 et seq.

${ }^{266}$ A preliminary reference led to Case C-399/11 Melloni. See the case note by A. Torres Pérez, 8 EuConst (2012) p. 105 et seq.

${ }^{267}$ A preliminary reference led to Case C-168/13 PPU Jeremy F. See A. Dyevre, 'If You Can't Beat Them, Join Them', 10 EuConst (2014) p. 154 et seq. 
hand, they can serve as an impulse, a driving force for the development of fundamental rights at EU level. This particular function must not be left to ordinary and specialized courts alone in the long run. The substantive coherence between national and Union fundamental rights - expressed today already in provisions such as Article 52(4) of the Charter - would thus receive a procedural or 'formal tie', ${ }^{268}$ Of course the ECJ will not always be able to meet the demands of national constitutional courts, as demonstrated by the Melloni judgment, doubtlessly worthy of criticism in its handling of the arguments of the Spanish Constitutional Court. ${ }^{269}$ That national constitutional and highest courts can nevertheless lay the foundations for an advancement of fundamental rights adjudication at EU level is illustrated by the ECJ's recent judgment on data retention - a milestone of fundamental rights protection at EU level. ${ }^{270}$

Karlsruhe had the chance to initiate this development already back in 2010 . May the Bundesverfassungsgericht henceforth remind itself of the path-breaking and exemplary nature of its widely acknowledged fundamental rights adjudication and seize such opportunity for the benefit of fundamental rights protection in Europe in the future.

${ }^{268}$ See already I. Pernice, Grundrechtsgehalte im Europäischen Gemeinschaftsrecht (Nomos 1979) p. 239-240.

${ }^{269}$ ECJ, Case C-399/11 Melloni, judgment of 26 Feb. 2013, paras. 55 et seq.

${ }^{270}$ ECJ, Joint Cases C-293/12 u. C-594/12 Digital Rights u.a. (Data Retention II), judgment of 8 April 2014. In addition to the reference by the Austrian Constitutional Court (C-594/12), the judgment also goes back to a reference by the Irish High Court (C-293/12). 